\title{
Determinants of Users Attitudes towards Social Websites Banner Advertising among University Students in Ethiopia
}

\author{
Eyob Ketema Worku \\ Business Adminstration Chairperson And Senior Lecturer \\ Lunar International College \\ P.O. Box 1774 Code 1250 Addis Ababa, Ethiopia
}

\begin{abstract}
Social websites (SWSs) have quickly developed in notoriety and user's acceptance comprehensively. Especially in recent years, they have become the fundamental spot for social relation, conversation, and correspondence. Today, numerous organizations promote their items on online social websites. The present study evaluates the impacts of social website on Ethiopian university students' beliefs and concerns of social website advertising (SWA) on their attitudes toward social website advertising and social websites banner advertisement clicking behavior. Information was gathered from a sample of 337 university students of five private colleges/university in Addis Ababa Ethiopia. Results shows the beliefs of social website advertising promoting as useful and engaging effectively affect client mentalities toward informal community publicizing and their advertisement clicking behavior. Likewise, client worry of social website advertising as aggravating has a beneficial outcome on both their social website advertising and advertisement clicking behavior. Further aggravation and offensive were seen as emphatically affecting advertisement clicking conduct of Ethiopian higher institution student's behavior towards SWA. The general outcomes shows that valuable and fascinating parts of social website advertising in Ethiopian higher institution students' viewpoint were shown to make social website advertising compelling.
\end{abstract}

Keywords:- Social websites; Social website advertising; banner Ad. clicking behavior, University students, Ethiopia.

\section{INTRODUCTION}

In the last decade, social media especially online social websites have quickly developed popularity and user acceptance (Mir,2012; taylor.et.al.2011). Recent estimates show that by 2020 social website users were 3.0 billion globally ( e-marketer,2020). Social websites are web-based applications which permit users to connect with other online users by creating personal profiles and inviting other users to visit those profiles. Other users can be friends, associates, family members, and outsiders. User profiles contain distinct data (e.g. age, gender, location, and interests) of users. They can likewise incorporate photographs, videos recordings, audio files and blogs
(Boyd \& Ellison,2007).Social websites not only encouraged user to user connectivity but also empowered organizations to showcase their items to their clients in a successful manner. Today numerous organizations promote their items on social websites (Constantinides \& Fountain ,2008; Kaplan \& Haenlein,2010;Saeedi,2012).

Advancements in internet and technology significantly influenced the ways of communication and in the last decade, social medias have strikingly changed the way people communicate (Edwards, 2011). Eagleman, (2013) indicated that social medias have become the primary channel for social interaction and communication using internet that enable users to communicate with different users online in addition to permitting users to create and exchange content online (Kaplan and Haenlein, 2010). Social media represents various online social communication platforms (e.g. social websites, multimedia sharing sites, bookmarking sites, wikies etc.). Moderately, the prominence and user adoption of social websites are quickly growing worldwide (Demerling, 2010; Kozel et al., 2013; Taylor,et.al.2011; Vasalou,et.al., 2010).

Several past studies examined the effects of factors such

(Diffley,et.al.2011;Hadija,et.al.2012;Kelly,et.al.2010;Sim \& Habel,2011; Roberts2010) irrelevant ads, lack of trust, and intrusiveness on social website users' behaviors toward social websites advertising (SWA). Nonetheless, least studies have assessed how user beliefs and concerns of SWA affects their attitudes toward SWA as well as their social websites banner ad-clicking behavior. Importantly, so far, the effects of user beliefs and concerns of SWA have not been theorized together in a single model in African perspective.

Understanding consumer beliefs of advertising is important as they affect their attitudes toward advertising (Pollay \& Mittal,1993). Similarly, consumer concerns of advertising as intrusive and irritating affect their attitudes toward online advertising (Baek \&,Morimoto 2012;:Ducoffe,1996) and ,user attitudes toward online advertising affect their ad-clicking behavior ( Wang \& Sun,2010). The current study aims to identify how users' views and beliefs affects their attitudes toward SWA and social websites banner ad-clicking behavior. Pollay and Mitall's (1993) framework is adopted and applied in the 
study to assess the effects of users' beliefs and concerns of SWA on their attitudes and behaviors toward SWA.

The framework has been found effective in measuring consumer attitudes and behaviors toward online advertising by several past studies (Wang \& Sun,2010; Korgaonkar P.et.al.2001).We all are witnessing a revolution in emerging information technologies such as wireless technology and mobile communication at the present time that make possible "anytime-any place "communication possible. As a result, companies in various industries have rapidly begun to integrate these technologies to their business models in order to exploit these opportunities (Yen and Chou, 2000).

Shoppers use web and social websites (SWSs) to find information that are supportive in buy process and in settling on right and hazard free item decisions (Cui and Roto, 2008 ;Park et al., 2009). Shoppers look for other purchasers' remarks and proposals on the web to loath the apparent hazard associated with a purchasing choice (Goldsmith and Horowitz, 2006). In like manner, they gather other shoppers' remarks and recommendations on social websites helpful in satisfying informative deficiency (Karlíček et al., 2012; Valenzuela et al., 2009). Shoppers additionally visit the promoting showing up on media (for example on social websites ) to assemble the data helpful in settling on risk free and better buy choices (Esfahani et al., 2012; notwithstanding, advertisement is a prevailing business wellspring of product information (Goldsmith, 2005).

Today, all sizes of organizations are promoting their products on social websites (neti,et.al. 2011; 2008; Kaplan $\&$ haenlein, 2010). Firms which promote their products and services on social websites to Ethiopian youth can profit by the discoveries of the current study especially, these discoveries will be useful in deciding the outcome of social websites banner advertisement content. In 2019, reported that 4.1 billion people were using the internet and cell phones, tablets were significant aces points using web and online trade showing an 18.4 per cent year-on-year growth per 100 inhabitants and reflecting a 5.3 per cent increase compared with 2018. Furthermore, in the least developed countries (LDCs), 19 per cent of individuals were online in 2019 where in Africa per 100 inhabitants, 34 were active mobile-broadband subscriptions( GSM,2019). In Ethiopia as of June 2018 ,internet penetration rate from the all-out populace is $18.5 \%$ and appropriately the clients grew 17.8 million of which larger part accessing the internet using a cell phone, (NBE,2018)

Therefore, the study result pertains to the relationships among views about, attitudes and behaviors towards social website advertising, could help advertisers produce conveniently advertising messages that reach audience more effectively in the Ethiopian context. Yet while research and practice have identified the promise of social websites advertising, little is known about the impact of social websites advertising in the Ethiopian context as the literature has largely focused on developed nations (wang, sun 2010a, 2010b; kamal,chu 2012). Consequently, the aim of the present study is to measure views and attitudes towards social websites advertising with respect to the Ethiopian cultural context and test a model which is proposed on the basis of previous researches made (Figure 1) linking views, attitudes, and behaviors related to social websites advertising.

The study hypothesizes the following, which are derived from the specific objectives and are tested in this study.

- H1a. Personal utility views of social website advertising have a positive effect on social websites users' attitudes toward social website advertising .

- H1b. Personal utility views of social website advertising have a positive effect on social website sites users' adclicking behavior.

- H2a. Socioeconomic belief of social website advertising as good for the economy has a positive effect on social website users' attitudes toward social website advertising .

- H2b. Socioeconomic views of social website advertising as deceptive, materialism and value corruption have negative effects on social websites users' attitudes toward social websites advertising .

- H3a. Intrusiveness and irritation have a negative effect on social websites users' attitudes toward social website advertising .

- H3b. Intrusiveness and irritation have a negative effect on social websites users' ad-clicking behavior.

- H4. Social websites users' attitudes toward social website advertising have a positive effect on their adclicking behavior.

\section{LITERATURE REVIEW}

\section{* Theoretical Literature \\ A. Introduction}

Since most recent couple of years, social media especially online social websites have quickly developed in ubiquity and client acceptance (mir, 2012; taylor.et.al.,2011). recent evaluations of e-marketer's show that social websites user will be 2.95 billion which is $77 \%$ of internet users globally will use a social website at least once per month in 2019 (emarketer,2019). social websites are web-based applications which permit users to associate with other online clients by making individual profiles and welcoming different users to visit those profiles. Different users can be companions, partners, family members and outsiders. Users profiles contain the clear data (for example Age, gender, location, and interests) of users. They can likewise incorporate photographs, recordings, sound documents and web journals (boyd,2007). social websites encouraged users to social websites availability as well as empowered organizations to advertise their items to their users in a successful manner. Today numerous organizations publicize their products on social websites (constantinides,et.al.,2008; kaplan and haenlein ,2010; saeedi ,2012). 
The impacts of variables such as, irrelevant ads, lack of trust, and intrusiveness on social websites users' behaviors toward social website advertising has been studied buy a few past studies (Diffley et.al.,2011; Hadija,et.al.,2012; Kelly,et.al.,2010; Sim and Habel ,2011; Roberts,2010). In any case, the impacts of user beliefs and concerns of SWA on their perspectives toward SWA and on their social websites banner ad-clicking behavior has been surveyed by few studies so far, the effects of user beliefs and concerns of SWA have not been hypothesized together in a single model. As a result understanding consumer beliefs of online advertising is significant as it influences users mentalities toward advertising (Pollay and Mittal ,1993).

Moreover, recent consumers' concerns toward online advertising as intrusive and disturbing is influencing their attitudes toward online advertising (Baek \& Morimoto,2012;Ducoffe,1996)and, also influences their ad clicking conduct (Ducoffe ,1996; Wang and Sun,2010). The current study survey users' views and concerns on their attitudes toward SWA and social websites banner adclicking behavior applying Pollay And Mitall's (1993) framework in African perspective.

\section{B. Social Websites and Online Communities}

The early online websites included a moderately modest number of Web fans, and users with extreme interests in innovation, political issues, writing, and ides. The innovation was to a great extent constrained to posting instant messages on announcement sheets supported by the community and coordinated or one-to-numerous messages. Notwithstanding the Well, early systems included GeoCities, a Website hosting service dependent on neighborhoods. By 2002, in any case, the idea of online websites had started to change. Client made Websites called online journals (blogs) got modest and simple to set up with no technical expertise. Photograph sites empowered advantageous sharing of photographs. Starting in 2007, the development of cell phones like cell phones, tablet PCs, digital cameras, and portable media gadgets empowered sharing of rich media, for example, photographs, music, and recordings. Out of nowhere there was a lot more extensive crowd for sharing interests and exercises, and substantially more to share (Laudon,2018).

The present social websites are as much a sociological marvel as they are an innovation wonder. At present, social websites support is one of the most widely recognized utilizations of the Internet. Very nearly $77 \%$ of all internet clients overall utilize interpersonal organizations (eMarketer, 2019). Proceeded with innovation and technology into wireless technologies furthermore, electronic gadgets, just as upgrades made in the territory of electronic business (web-based business) have cultivated the formation of mobile business (m-commerce) (Senn 2000). Buyers presently have shopping platforms truly at the tip of their thumb, look through suppliers' applications, save their preferred items, add them to lists of things to get, and enjoy further instant purchase and observe now shopping society. S-commerce goes even further in that it includes an assortment of buyer instruments to mingle and share business related data (Lin et al. 2017).

Social media platforms, for example, Facebook, Twitter, Instagram, and Pinterest, have additionally changed the business world (Fraser and Dutta 2008). Organizations are done broadcasting their messages as a monolog, however are (ideally) effectively captivating into a discourse with their purchasers. Organizations can share their recordings, blogs, and item data, or even offer conversation starters and surveys to empower reactions in a successful and productive manner, contacting a worldwide crowd, while customers have the chance to share this content or make their own, remark on links, like pictures, or offer their interests momentarily and continuously. Our reality has changed to getting progressively straightforward, with each activity causing a much more prominent response that is communicated comprehensively, with everybody viewing (for example Doherty and Delener 2001; Kaplan and Haenlein 2010).

\section{What is an Online Social media?}

Social media can be characterized as "a gathering of internet-based applications that work with respect to the ideological and specialized establishments of Web 2.0, and that permit the creation and trade of client produced content" (Kaplan and Haenlein 2010, p. 61). The most well-known Social media are Facebook, YouTube, Instagram, Twitter, Pinterest and SWApchat (Phua et al. 2017), and Chinese Social media sites Sina Weibo and WeChat (Taylor and Kent 2014). Because of the emergence of cell phones, there has been a gigantic increment in Social media utilization in the course of the most recent couple of years, with sites, for example, Facebook now being readily available on these handheld PCs, encouraging moment and regular access (Morrow 2014). In spite of the current pattern to eliminate long range interpersonal communication and to have a 'digital detox', more individuals than any other time in recent memory are utilizing web-based life (Mintel 2018). This features the ubiquitous nature of social media and the potential marketing and sales power it harnesses for brands across the globe.

Studies demonstrates that buyers see online social media sites to be more dependable wellsprings of information, likely because of a disintegration of certainty in the information received by means of conventional publicizing (Mangold also, Faulds 2009; Christodoulides et al. 2013). Then, brands are withdrawing from single direction interchanges of their messages by means of nonfocused on publicizing in customary media (for example Television, radio, magazine and standard mail) to utilize social media as an implicit promoting instrument that shapes two-route correspondences among brands and clients, addressing at huge number of clients in a brief timeframe and for less cost (Keller 2009; Tiago and Veríssimo 2014; Scott 2015). Subsequently, so as to increase revenues, brands are concentrating a greater amount of their endeavors via web-based social media and attempting to improve their correspondence and 
associations with shoppers on these stages (Grizane and Jurgelane 2017).

\section{The growth of social websites and online communities}

A maturing populace has seen an expansion in more older individuals shopping on the web (Kuo et al. 2012) which features the requirement for inclusivity in web architectures and social media strategies. Notwithstanding well-known misguided judgments, more older customers don't feel like there are a larger number of dangers related with shopping online than more youthful purchasers do (Kwon and Noh 2010) and the study by Boardman and McCormick (2018) shows that all ages from 20 to 70 years are presently shopping online routinely, and that all aside from the $60 \mathrm{~s}$ age group peruse on their cell phones for garments. This is likewise valid for social media use: in spite of Facebook utilization declining with age, it is still exceptionally well known among all age groups, topping among 25-34-year olds with $83 \%$ of individuals in that age group utilizing it, principally on the grounds that they were the fundamental adopters from the launch in 2006 (Mintel 2018).

However, in spite of an expanding number of older individuals utilizing the web and shopping on the web, there may in any case be contrasts in their conduct and perspectives towards online retailing and brands via social media. For instance, Zimerman (2012) found that twenty to thirty year old's (those conceived approx. 1980-1999) utilized sites including Google and Wikipedia considerably more than more older clients, which recommends that more youthful clients may search for data more than more older clients on the web. Additionally, Goodrich (2013) found that more older clients gave more consideration to online banner promotions than more younger clients. Moreover, research shows that customers have various mentalities towards brands and shopping. For example, Parment (2013) found that for twenty to thirty year old, their enthusiasm for the item impacts their buying decision more than it does for Baby Boomers, which recommends that millennials are all the more emotionally involved when purchasing items. Additionally, Parment (2013) found that recent millennials are considerably more worried about how others see them, though Baby Boomers are less intrigued by what others think. millennials are more adaptable and less brand steadfast than Baby Boomers, and do not require as much assistance from deals aides when purchasing items, while Baby Boomers like to shop at simply the one shop however much as could be expected. This feature various periods of customers have different perspectives towards shopping and vary in their shopping conduct, which may have intriguing ramifications for whether they follow brands via social media, especially as some are more brand steadfast than others.

\section{* Empirical Literature}

\section{A. Consumer Beliefs and Concerns}

Descriptive thoughts that individuals hold about others ,occasions, things etc. are referred as beliefs (Kotler \&Keller ,2006). Pollay and Mittal (1993) also characterized buyer beliefs towards advertising into two classes: Personal utility and socioeconomic beliefs. Shoppers' own utility beliefs of advertising comprise of three measurements for example useful, engaging, social role and image. socioeconomic beliefs contain four measurement for example tricky, spreading realism, esteem debasement and useful for the economy. So also, customer uncertainties of advertising are characterized into two measurements for example intrusiveness and irritation/aggravation ( Edwards et.al.,2002).

\section{B. Personal Utility Beliefs}

The essential capacity of advertising is giving item information to shoppers (Ackerberg ,2003; Alwitt,1992). Advertising gives buyers information about the nature, highlights, capacities, and accessibility of the items ( Bucklin LP.,1965). This information empowers shoppers to settle on the judicious item decisions (Norris VP.,1984). Be that as it may, a commercial cannot be informational except if purchasers perceive it all things considered (Puto CP.\& Wells WD.,1984). A few past researchers (Wang and Sun ,2010;Ling KCet.al.,2010; Nan X.,2006) identified with customary and online advertising recognized that shoppers perceive advertising as a significant wellspring of information.

They additionally found that customer beliefs of advertising as useful impact their mentalities toward advertising positively.Other than beliefs of advertising as useful, customers perceive it as a wellspring of libertine worth or amusement (Ducoffe,1995). Indulgent qualities (for example sentiment of fun, delight and so on.) are mental in nature (Srinivasan,1987). Introduction to advertising can engage shoppers by satisfying their feelings (Jones,1999). Buyers perceive conventional (Tan and Chia , 2007) and online advertising (Pollay \&Mittal,1993;Wolin and Korgaonkar ,2005) as engaging. Perceived diversion positively affects buyer mentalities toward advertising (Pollay \&Mittal,1993;Tan and Chia ,2007; Jamalzadeh,2012).

Some past research (Mahmoud,2012;Petrovici and Marinov,2007;Yaakop,et.al.2011) recognized that buyers perceive advertising supportive in improving their social roles and image. Advertising regularly presents the fanciful circumstance demonstrating how customer will feel and take care of utilizing the publicized brand. This spurs customers to purchase the publicized brands to help their genuine and perfect social images ( Pollay and Mittal,1993). Then again, some past research (Tan and Chia,2007; Mittal,1994) distinguished that customers do not perceive advertising accommodating in improving their social role and image.

\section{Socioeconomic Beliefs}

In spite of the disputable idea of advertising consumers see it useful for the economy ( Pollay and Mittal,1993; Wang and Sun ,2010). Advertising gives item information, prompts lower costs, and advances sound rivalry between organizations which at last advantage the purchasers. It is the astute utilization of national assets( Pollay and Mittal,1993). Advertising rouses the customers 
to improve their way of life (Wang and Sun ,2010).Furthermore, promoting advertising information decreases the consumers search cost. Wang and Sun (Wang and Sun ,2010) distinguished that useful for the economy beliefs positively affects customer attitudes toward online advertising.

Advertising is asserted for spreading materialism and covetousness in a general public. It makes such needs and wants that buyers may never perceive all alone ( Wang and Sun ,2010). Materialism is characterized as the significance which customers append to common belongings. Materialists see the common belongings as the best wellsprings of fulfillment and disappointment. Purchasers accept that through items, topics and execution procedures advertising makes them materialistic (Aziz and Ariffin ,2010;Petrovici and Paliwoda,2007;Polak and Mccullough ,2006). This belief impacts purchaser attitudes toward customary (Tan and Chia,2007) and online advertising adversely (Aziz and Ariffin ,2010).

Advertising is frequently condemned for spoiling social qualities. It endeavors to bargain the social qualities (Wang and Sun ,2010) by continually strengthening the qualities harming topics to impact consumer behavior. Publicists frequently utilize sexual stimuli in advertisements which advance indecency in a general public. Advertising influences relational connections and the family esteems. Particularly, it influences the role of ladies and youngsters in a general public (Pollay,1986). Social values are midway held intellectual components which guide how to behave in a society. Change in the social values can prompt social issue and disarray (Pollay RW.,1983). Consumers believe that online advertising defiles their social values and this conviction impacts their attitudes toward online advertising contrarily (Wang and Sun ,2010; Wolin ,et.al.,2002). It is a general discernment that advertising bamboozles buyers. Shoppers accept that advertising does not depict a genuine image of the item. It affronts the insight of the normal shopper (Yang,2000). Darke and Ritchie(2007) expressed that customers do not have to realize precisely how advertising claims deceive them. They just need to see an error between the advertising guarantee and the genuine exhibition of the advertised item to distinguish that they have been hoodwinked. Trickiness has essentially a negative impact on buyer attitudes toward advertising (Eze and Lee,2012).

\section{Consumer Concerns}

Ads are intended to deliver constructive outcomes of significant worth to both advertiser and buyer. Be that as it may, they may likewise create negative impacts. One such negative impact is customers may see the commercial as intrusive (Ying,et.al.,2009) .Truonga and Simmons (2010) recognized that shoppers see web advertisements as meddling. Likewise, Sim and Habel ( 2010) found that clients see social media advertising as intrusive. Commercials by design produce interference however clients may consider this interference as interruption when it disturbs their line of reasoning (McCoy,et.al.,2008). Edwards et al.(2013) characterized intrusiveness as "how much an individual regards the introduction of data as in spite of their objectives". View of meddling at last influences purchaser attitudes and practices toward advertising (Nan,2006; Ying,et.al.,2009).

Past analysts (Baek and Morimoto,2012; Ducoffe, 1996) distinguished that clients see advertising on web just as via web-based social media bothering. Irritating advertisements anger viewers, cause disappointment and flitting restlessness. Irritation delivers the negative impact and the most exceedingly terrible thing is that it could decrease the validity of all advertising. Impression of irritation impact customer attitudes toward web promoting adversely (Ducoffe,1996). Baek and Morimoto (2012) recognized that apparent irritation prompts advertisement avoidance. On the other hand, some past studies (Edwards et.al.,2013) found no critical relationship between the apparent irritation and promotion avoidance on the web. MySpace and Facebook clients communicated that SWA does not bother them or hinder their exercises on these sites (Kelly,2010).

\section{E. Users Attitudes \& online Advertisement Clicking Behavior}

Attitude is a person's certain or contrary sentiments and assessments about playing out a specific conduct and understanding an individual's outlook is significant since it impacts individual goals. (Fishbein and Ajzen,1975). Korgaonkar and Wolin (2005) and Wang and Sun (2010) found that advertisement clicking conduct of users is influenced by buyers' attitudes toward online advertising. Usually, users initiate clicking on online banner ads which basically moves users from the current website page to the advertiser's website page where the user will be presented with and additional further information presenting the user to buy an item or service (Chatterjee P.et.al.,2003; Hofacker and Murphy,1998).

However ad-click rates are viewed not only as significant proportions of banner advertising adequacy (Chandon JL.et.al.,2003;Cho CH,1999) but also as an indicator whether the shopper visited the advertiser's webpage and finished an item purchase. Click on the online ads makes it simple for the advertiser to track and measure the impacts of online advertising ( Pavlou \&Stewart,2000). It is the immediate and quick reaction of clients to online advertisement presentation ( (Chatterjee P.et.al.,2003).

\section{* Conceptual Foundations \\ A. Conceptual Model}

Pollay and Mittal's (1993) framework applied in the study to determine the impacts of users' beliefs and concern of SWA on their attitudes and conduct toward SWA in Ethiopia. Pollay and Mittal's (1993) framework illuminates the relations of users' general belfries towards advertising with individual's utility and socioeconomic advertising beliefs, where individual utility beliefs clarify how an individual sees the advertising at individual level. At individual level buyers see advertising as educational, engaging, and supportive in improving social role and 
image (Nan X.,2006; Yaakop,et.al.2011b;Petrovici and Marinov,2007;Eze and Lee,2012).

Socioeconomic beliefs clarify purchasers' macro perceptions of advertising. For instance, useful for the economy, misleading buyers, spreading realism, and corrupting social values ( Pollay and Mittal,1993; Wang and Sun ,2010). A few past investigations (Tan and Chia,2007; (McCoy,et.al.,2008;Bamoriya and Singh ,2011) discovered Pollay and Mittal's (1993) belief framework viable in estimating shopper attitudes toward conventional advertising (for example TV advertising).

Thus, past researchers'(Wang \& Sun,2010; Korgaonkar P.,2001) also discovered that Pollay \& Mittal (1993) framework is successful in estimating shopper attitudes toward online advertising. Therefore ,the current study also proposes in a similar manner that individual utility and socioeconomic beliefs about SWA influence social website users' attitudes toward SWA which also influence their online banner ad-clicking conduct (figure1). Wolin and korgaonkar,(2002) ;Wolin,et.al.,(2002)and Wang and Sun (2010) found that users attitudes toward SWA and their ad-clicking conduct influenced by their beliefs about SWA. similarly, Rosenberg (1956) and Ahtola (1985) suggested that practices can directly be influenced by beliefs. In this manner, the current study hypothesizes that individual utility beliefs about SWA directly affect clients' social website banner ad clicking conduct.

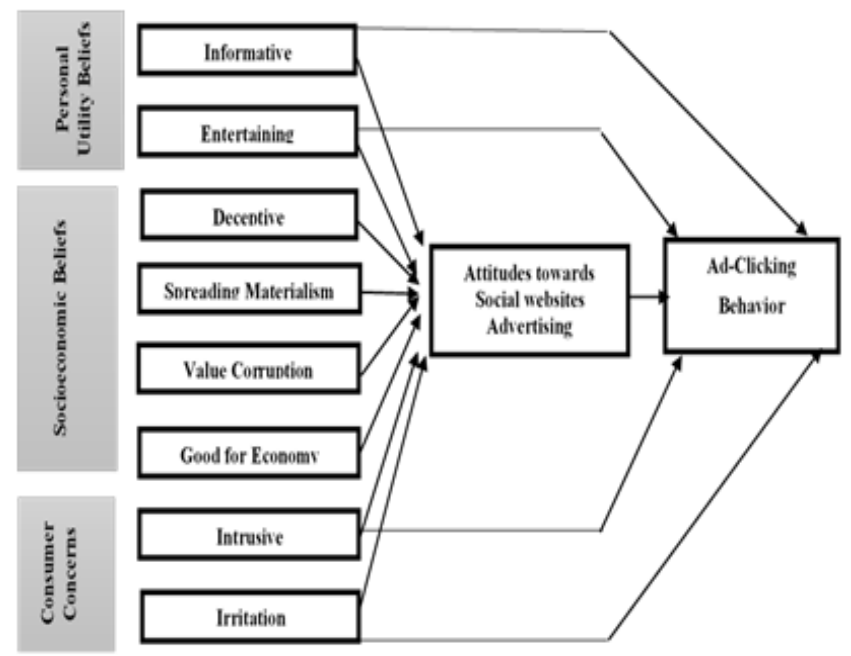

Fig 1:- The Research Framework

Source ; Attitudinal and Behavioral Model of social network advertising. Adopted from Imran Mir,(2015) study

\section{METHODOLOGY}

A quantitative study with exploratory research design is adopted under this study, where survey research approach is followed since it offers numeric description of trends, attitudes, or opinions of a population by studying a sample of the population(Cooper \&Donald,2014).A survey questionnaires a cross-sectional data is collected with the intent of generalizing from a sample to a population consequently, descriptive research is selected (Creswell ,2014).For the present research, the target population comprises of Students of five major private universities in Addis Ababa which is the most populous in the country furthermore; where a large number of universities and colleges are available compared to other parts of the country. The universities St. Marry university, Admas university, Micro link information technology college, Unity university, and Lunar International college are chosen considering the fact that the researcher is being a currently a lecturer in three of the universities and have points of contact with faculty members in the remaining universities/colleges that can easily help in distributing and collecting the research instrument .

For the target population a non-probability sampling method, convenience sampling is used to select the five universities/colleges while, respondent university students from the population are selected using stratified random sampling where a population is divided into the appropriate strata, and a simple random sample is taken within each stratum. In a similar manner the simple random sampling procedure is applied for each stratum since probability sampling method is less costly and saves time. Moreover, it is also the only feasible alternative sampling method as a result that the total population may not be available for this study (Cooper \&Donald,2014). The total population for this study is estimated to be around 35,270 and taking the rational discussed earlier the sample size for the study is 384. Following With, 95\% confidence interval and 0.05 the confidence interval (also called margin of error) sample determination of calculation ( Israel,2013) done as follows ;

$$
\begin{aligned}
& \text { Sample } \\
& \text { size }= \\
& \mathrm{c}^{2}
\end{aligned}
$$

Where:

$\mathrm{Z}=\mathrm{Z}$ value (1.96 for $95 \%$ confidence level)

$\mathrm{p}=$ percentage picking a choice, expressed as decimal $(.5$ used for sample size needed)

$\mathrm{c}=$ confidence interval, expressed as decimal $(.05= \pm 5 \%)$ 
ISSN No:-2456-2165

\begin{tabular}{|c|c|c|c|c|c|c|}
\hline S. no & Universities & $\begin{array}{c}\text { No of campuses } \\
\text { in Addis Ababa } \\
(\mathbf{2 0 1 9})\end{array}$ & $\begin{array}{c}\text { No of } \\
\text { students ( as } \\
\text { of Aril 2019) }\end{array}$ & Proportion & $\begin{array}{c}\text { Samples } \\
\text { required for } \\
\text { the study }\end{array}$ & Samples taken \\
\hline $\mathbf{1}$ & St. Marry university & 2 & 7,518 & 0.21 & 384 & $\mathbf{8 2}$ \\
\hline $\mathbf{2}$ & Admas university & 4 & 13,436 & 0.38 & 384 & $\mathbf{1 4 6}$ \\
\hline $\mathbf{3}$ & $\begin{array}{c}\text { Micro link } \\
\text { information } \\
\text { technology college }\end{array}$ & 1 & 1,237 & 0.04 & 384 & $\mathbf{1 3}$ \\
\hline $\mathbf{4}$ & Unity university & 1 & 12,345 & 0.35 & 384 & $\mathbf{1 3 4}$ \\
\hline $\mathbf{5}$ & $\begin{array}{c}\text { Lunar International } \\
\text { College }\end{array}$ & 1 & 734 & 0.02 & 384 & $\mathbf{8}$ \\
\hline & Total & $\mathbf{9}$ & $\mathbf{3 5 , 2 7 0}$ & $\mathbf{1 . 0 0}$ & & $\mathbf{3 8 4}$ \\
\hline
\end{tabular}

Table 1:- Sample size

Source: Universities registrar data, May 2019

\section{A. Measurements and data collection}

The questionnaire used in the study uses a five-point Likert scale to measure the variables. Scales to measure each variable is developed based on prior related studies. To measure social website users' personal utility beliefs about SWA a pool of 18 items were generated from Mir (2011), Petrovici and Marinov (2007); Pollay and Mittal(1993), Tan and Chia(2007), Taylor et al.(2011) and Wang and Sun(2010). To measure social websites users' socioeconomic beliefs of SWA an inventory of 20 items is generated from Mir (2011), Tan and Chia(2007), Wolin et al.(2005). To measure user concerns of SWA an inventory of 12 items were generated from Edwards et al.(2011) and $\mathrm{Li}$ et al.(2002). To measure consumer attitudes toward SWA 7 items were generated from Pollay and Mittal(1993), Tan and Chia(2007), Taylor et al.(2011) and Wang and Sun,(2010) ,Mir, (2011). To measure users' social website banner ad-clicking behavior 3 items were adapted from Mir (2011).

The survey questionnaire has two parts; the first part of the questionnaire is used to identify prospective of respondents' interest of social website service media. This section also asks the respondents for their demographic information (gender, and age). The second part of the questionnaire measures the relevant constructs of interest to this study that includes series of 40 statements that covered related construct dimensions (personal utility beliefs, Socioeconomic belief, users' attitudes, consumers concern ) influence users' attitudes affects toward social website advertising and social website banner ad-clicking behavior. The constructs are measured on a five-point Likert-type scale ranging from 1 (strongly disagree) to 5 (strongly agree).

\section{B. Reliability Analysis and Factor Analysis}

Cronbach $\alpha$ was used to analyze the internal consistency of the variables used in the study. According to Cuieford (1977), Cronbach $\alpha$ above 0.7 indicates high internal consistency while Cronbach $\alpha$ below 0.35 indicating poor internal consistency of a scale since the items that make up the scale are poorly related to each other. The reliability analysis of the variables - Informative,
Entertaining, Deceptive, Materialism, Value Corruption, Promotes Economy, Intrusive, Irritation, and user Attitudes ad-clicking behavior are indicated in Table 2 below showing a Cronbach $\alpha$ value is between 0.714 and 0.788 , which are all above 0.7.dimensionally. If you must use mixed units, clearly state the units for each quantity that you use in an equation.

\begin{tabular}{|c|c|}
\hline Variables & Cronbach's Alpha \\
\hline Informative & .768 \\
\hline Entertaining & .758 \\
\hline Deceptive & .748 \\
\hline Materialism & .749 \\
\hline Value Corruption & .750 \\
\hline Promotes Economy & .779 \\
\hline Intrusive & .748 \\
\hline Irritation & .788 \\
\hline User Attitudes & .714 \\
\hline
\end{tabular}

Table 2

\section{* Reliability of instrument used}

\section{A. Scale purification and dimensions}

Factor analysis was used for confirmatory purpose i.e. confirmatory factor analysis (CFA) to determine only the relationships between a factor and specific items since the researcher have already a clear expectations of the factor structure ( the scale measurements already adapted in this study has been proposed by previous researchers) and the researcher wants to test for the expected structure.

In performing a factor analysis, the following steps has been taken, which is important.

Performing a factor analysis on the variables used necessary is determined . for the factor analysis to make sense the focus is that the correlation between the variables is the bases on finding a number of underlying dimensions Consequently, indications were obtained by examining the anti-image correlation matrix, such as, 'Bartlett's test of sphericity' and 'Kaiser-Meyer-Olkin measure of sampling adequacy’ (MSA). 


\begin{tabular}{|c|c|c|}
\hline \multicolumn{3}{|c|}{ KMO and Bartlett's Test } \\
\hline \multicolumn{2}{|c|}{$\begin{array}{c}\text { Kaiser-Meyer-Olkin Measure of Sampling } \\
\text { Adequacy. }\end{array}$} & .843 \\
\hline \multirow[t]{3}{*}{$\begin{array}{l}\text { Bartlett's Test of } \\
\text { Sphericity }\end{array}$} & $\begin{array}{l}\text { Approx. Chi- } \\
\text { Square }\end{array}$ & 7710.228 \\
\hline & Df & 435 \\
\hline & Sig. & .000 \\
\hline
\end{tabular}

Table 3

Exploring factor analysis for service quality scale KMO and Barlett's Test

According to Kaiser (1974) MSA lies between 0 and 1, and values above .50 are considered acceptable. Therefore, the result $0.843>0.50$ tells us that the factor analysis useful in this study data. Small values (less than 0.05) of the significance level indicate that a factor analysis may be useful with in the study data this tells us that for this study factor analysis is very important since the significance is less than0.05 (i.e.0.000)
A method to extract factors was chosen; the varimax rotation (the default option for orthogonal rotation in SPSS) is used for CFA since it is the best-known one and this procedure aims at maximizing the dispersion of loadings within factors, which means a few variables will have high loadings, while the remaining variables' loadings will be considerably smaller (Kaiser 1958).

The number of factors were Determined; Given the fact that, more factors are extracted as an increasingly smaller portion of the variance in the original data is explained and at the expense of the smallest possible loss of explanatory the researcher may also limit the number of relevant factors which is based on a subjective procedure and consequently the researcher can use the following criteria's to determine this number: (1) the 'Kaiser criterion', which will only retain those factors for which the Eigenvalue is greater than one, and thus only those factors which explain a minimal portion of the variance and ; (2) a 'Scree plot', is the most common tool used that shows the evolution of the Eigenvalue, and recommends the amount of factors to be retained diagrammatically.

\begin{tabular}{|c|c|c|c|c|c|c|c|}
\hline \multirow{2}{*}{ 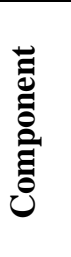 } & \multicolumn{3}{|c|}{ Initial Eigenvalues } & \multicolumn{3}{|c|}{ Extraction Sums of Squared Loadings } & \multirow{2}{*}{$\begin{array}{c}\text { Rotation } \\
\text { Sums of } \\
\text { Squared } \\
\text { Loadings }\end{array}$} \\
\hline & Total & $\begin{array}{c}\% \text { of } \\
\text { Variance }\end{array}$ & Cumulative \% & Total & $\begin{array}{c}\% \text { of } \\
\text { Variance }\end{array}$ & Cumulative \% & \\
\hline 1 & 5.131 & 21.379 & 21.379 & 5.131 & 21.379 & 21.379 & 3.631 \\
\hline 2 & 3.943 & 16.429 & 37.808 & 3.943 & 16.429 & 37.808 & 2.730 \\
\hline 3 & 2.239 & 9.328 & 47.136 & 2.239 & 9.328 & 47.136 & 2.677 \\
\hline 4 & 1.703 & 7.096 & 54.232 & 1.703 & 7.096 & 54.232 & 2.252 \\
\hline 5 & 1.605 & 6.688 & 60.920 & 1.605 & 6.688 & 60.920 & 2.193 \\
\hline 6 & 1.212 & 5.051 & 65.970 & 1.212 & 5.051 & 65.970 & 1.752 \\
\hline 7 & 1.113 & 4.638 & 70.608 & 1.113 & 4.638 & 70.608 & 1.711 \\
\hline
\end{tabular}

Table 4:- Total Variance Explained

\section{Extraction Method: Principal Component Analysis}

In addition, factor analysis depends on Eigenvalue in determining the number of factors and only factors with Eigenvalue greater than 1 are kept in the model since the researcher has a clear picture beforehand of the number of dimensions sought were eight ( Wim Janssens .et al.2008).

An oblique rotation was chosen ; an ideal factor structure scenario condition is created where a strong correlation either insignificantly or not among each other is displayed by every original scale measurement used and that way expressive explanation may be provided by every factor and every fundamental measurement of the data set (Darren and paul,2019) where the factor loadings for some of the variables will be as close as possible to 1 , and as close as possible to 0 for the other factors. A rotation of the factors is thus recommended as a result, an oblique rotation (the factors are correlated after rotation, and thus no longer independent from one another) default varimax rotation is used to simplify the interpretation of the factors, whereby by minimizing the number of variables which have high loads on each of the factors (Darren and paul,2019).

\section{B. Exploratory Factor Analysis}

As the research uses factor extraction principal component method, factor loading coefficients must have weights greater than 0.5 (Darren and paul,2019). Originally the research Model proposes Nine factors relationship (containing 33items), 8 Factors representing independent Variable (30 observed variables) and 1 Factor representing 3 Independent items (the factors are also independent of one another after rotation may be seen in the 'Component Score Covariance Matrix' attached in the annex ). 
Following the conceptual, practical considerations and based on practical sets of variables the results are indicated as follows. The acceptance of factor loadings of 0.50 and above are considered but in some cases depending on the study type a cross loadings of above 0.40 is considered practically significant by most researchers normally (Wim Janssens .et al.2008). Cronbach alpha coefficient of all 24 variables have high reliability then confirmatory factor analysis (CFA) is utilized to reassess the convergence of observed variables around the main components (Table 5). Using principal components analysis and varimax rotation method at every level of Eigenvalues greater than 1 and, 7 variables have been extracted from 24 observed item variables with a cumulative variance $70.608 \%$ explaining ability satisfied. (which is greater than $50 \%$ ).

\begin{tabular}{|c|c|c|c|}
\hline Key dimensions and items & Loadings & Communalities & Reliability \\
\hline Informative & & & 0.768 \\
\hline Social websites ads are a valuable source of product /service & .793 & .705 & \\
\hline Social websites ads are a convenient source of product/service & .796 & .683 & \\
\hline Social website ads help keep me up to date about product & .764 & .610 & \\
\hline \multicolumn{4}{|l|}{ Informative $($ Eigenvalue $=5.131 ;$ Variance $=21.379 \%)$} \\
\hline Entertaining & & & 0.758 \\
\hline Social websites ads are entertaining & .722 & .724 & \\
\hline Social websites ads are enjoyable & .724 & .707 & \\
\hline Social websites ads are pleasing & .693 & .673 & \\
\hline \multicolumn{4}{|l|}{ Entertaining $($ Eigenvalue $=5.131 ;$ Variance $=21.379 \%)$} \\
\hline Social Website Advertising are Deceptive & & & 0.748 \\
\hline $\begin{array}{c}\text { 1. Most Social Website Advertising insults the intelligence of the average } \\
\text { consumer }\end{array}$ & .758 & .685 & \\
\hline $\begin{array}{l}\text { 2. Product information provided in Social Website Sites ads are not } \\
\text { trustworthy }\end{array}$ & 827 & .727 & \\
\hline $\begin{array}{l}\text { Social Website Advertising does not help the consumer to buy the best } \\
\text { brands for the price }\end{array}$ & .761 & .690 & \\
\hline 4. Social Website Advertising is manipulative & .433 & .516 & \\
\hline \multicolumn{4}{|l|}{ Deceptive $($ Eigenvalue $=1.605 ;$ Variance $=6.688 \%)$} \\
\hline Materialism & & & 0.749 \\
\hline $\begin{array}{l}\text { Social Website Advertising is making us a materialistic society- } \\
\text { interested in buying \& owning things }\end{array}$ & .835 & .747 & \\
\hline $\begin{array}{l}\text { 2. Social Website Advertising makes people buy unaffordable products just to } \\
\text { show off }\end{array}$ & .673 & .578 & \\
\hline Social Website Advertising makes people live in a world of fantasy & .634 & .603 & \\
\hline \multicolumn{4}{|l|}{ Materialism $($ Eigenvalue $=1.703 ;$ Variance $=7.096 \%)$} \\
\hline Value Corruption & & & .750 \\
\hline Social Website Advertising promotes undesirable values in our Society & .841 & .781 & \\
\hline Most of the Social Website Advertising distorts the values of the youth & .822 & .790 & \\
\hline Social Website Advertising takes undue advantage of teenagers & .511 & .521 & \\
\hline \multicolumn{4}{|l|}{ Value Corruption $($ Eigenvalue $=\mathbf{1 . 2 1 2} ;$ Variance $=\mathbf{5 . 0 5 1 \%}$ ) } \\
\hline Promotes Economy & & & .779 \\
\hline Social Website Advertising helps raise our standard of living & .783 & .665 & \\
\hline $\begin{array}{l}\text { In general, Social Website Advertising has a positive effect on our nation's } \\
\text { economy }\end{array}$ & .779 & .766 & \\
\hline \multicolumn{4}{|l|}{ Promotes Economy $($ Eigenvalue $=1.113 ;$ Variance $=\mathbf{4 . 6 3 8 \%})$} \\
\hline Intrusive & & & 0.748 \\
\hline I find ads shown on Social Websites' distracting & .889 & .762 & \\
\hline I find ads shown on Social Websites' disturbing & .822 & .841 & \\
\hline I find ads shown on Social Websites' forced & .797 & .753 & \\
\hline
\end{tabular}


ISSN No:-2456-2165

\begin{tabular}{|c|c|c|c|}
\hline Intrusive $($ Eigenvalue $=3.943 ;$ Variance $=16.429 \%)$ & & & \\
\hline Irritation & & & .788 \\
\hline I find ads shown on Social Websites' ridiculous & .871 & .799 & \\
\hline I find ads shown on Social Websites' senseless & .834 & .783 & \\
\hline I find ads shown on Social Websites' awful & .883 & .824 & \\
\hline \multicolumn{3}{|l|}{ Irritation $($ Eigenvalue $=2.239 ;$ Variance $=9.328 \%)$} & \\
\hline Overall Reliability & & & .772 \\
\hline
\end{tabular}

Table 5:- Factor Loading, Communalities and Reliable Analysis for the independent dimensions

Extraction Method: Principal Component Analysis.

Rotation Method: Varimax with Kaiser Normalization.

Rotation converged in 8 iterations.a

As indicated in table 5 the scale is reliable indicated by the composition of each factor has a Cronbach's Alpha value of 0.772. The Informative scale (three items) contains Entertaining (three items), Deceptive (there items), Materialism ( Three items), Value Corruption,( Three items), Promotes Economy ( two items), Intrusive,( Three items), Irritation,( Three items) . After trial testing, using the largest variance in the orthogonal rotation factor analysis Informative scale (three items) and Entertaining (three items) have been grouped together. This is not a surprise result considering the high commonality and relationship that exists among the variables that resulted a 21.379 percent cumulative variance explained. After conducting CFA, the Cronbach's Alpha value of the composition of each factor found to be greater than 0.7 , showing that the scale measurement is still reliable.

\section{RESULT}

\section{A. Response Rate}

\begin{tabular}{|c|c|c|c|}
\hline Sample Frame & Category & Pample size & Percentage \\
\hline \begin{tabular}{c} 
Selected Private University students in Addis $\begin{array}{c}\text { No. Distributed } \\
\text { Ababa, Ethiopia }\end{array}$ \\
\cline { 2 - 4 }
\end{tabular} & No. Response & 384 & $100 \%$ \\
\cline { 2 - 4 } & $\begin{array}{c}\text { No. Discarded due to } \\
\text { Incompetence }\end{array}$ & 13 & $31 \%$ \\
\cline { 2 - 4 } & Qualified surveys remained & 337 & $88 \%$ \\
\hline
\end{tabular}

Table 6:- Response Rate

\section{B. Sample Characteristics}

Demographic data shown in table 5 showed that majority of respondents were male: (224) constitute 73.7 percent and the respondents' age group $47 \%$ is between 18 to 35 years old followed by $45 \%$ from 36 to 55 years old. Similarly, the table shows that $58.2 \%$ of the respondents are a private company employee while $14.8 \%$ are engaged in a Professional/Private business.

Looking at the social website site usage of respondents the $72 \%$ of the respondents claimed that they use Facebook while $43.9 \%$ said that they Google + and the remaining $22.6 \%$ and $25.5 \%$ of the respondents indicated that they use twitter, Facebook and Google + and Other site respectively.

\begin{tabular}{|c|c|c|c|c|}
\hline No. & Profile & Description & Percentage (\%) & Responses \\
\hline 1 & Age (in Years) & Below 25 years old & $25.8 \%$ & 87 \\
\hline & & $25-34$ years old & $51.6 \%$ & 174 \\
\hline & & $35-44$ years old & $22.0 \%$ & 2 \\
\hline & & $45-50$ years old & $0.6 \%$ & 0 \\
\hline & & Above 51 years old & $0 \%$ & 147 \\
\hline 2 & Gender & Male & $43.4 \%$ & 2 \\
\hline & & Female & $56.4 \%$ & 25 \\
\hline 3 & Level of Education & Student & $0.6 \%$ & 231 \\
\hline & & Secondary Certificate & $7.4 \%$ & 79 \\
\hline & & Diploma & $68.5 \%$ & 2 \\
\hline & & Bachelor's Degree & $23.4 \%$ & 0 \\
\hline
\end{tabular}


ISSN No:-2456-2165

\begin{tabular}{|c|c|c|c|c|}
\hline 4 & $\begin{array}{c}\text { Which social websites do you } \\
\text { use more often? }\end{array}$ & Facebook & $71.8 \%$ & 242 \\
\hline & & Google+ & $43.9 \%$ & 148 \\
\hline & & My Space & $1.2 \%$ & 4 \\
\hline & & Twitter & $22.6 \%$ & 76 \\
\hline & & Facebook and Google + & $25.5 \%$ & 16 \\
\hline & & Facebook and twitter & $4.7 \%$ & 21 \\
\hline & & Google and My Space & $6.2 \%$ & 79 \\
\hline & & Others & $23.4 \%$ & 0 \\
\hline & & All of them & $0.0 \%$ & $\mathbf{3 3 7}$ \\
\hline
\end{tabular}

Table 7:- Demographic Profile

Further analysis indicated that majority of the respondents (115) indicated that they use one social website site while 94 respondents said that they use two social websites while 81 respondents claiming that they use three social websites. Similarly, out of the total selected respondents 28 and 5 respondents indicated that they use four social website site and five social websites.

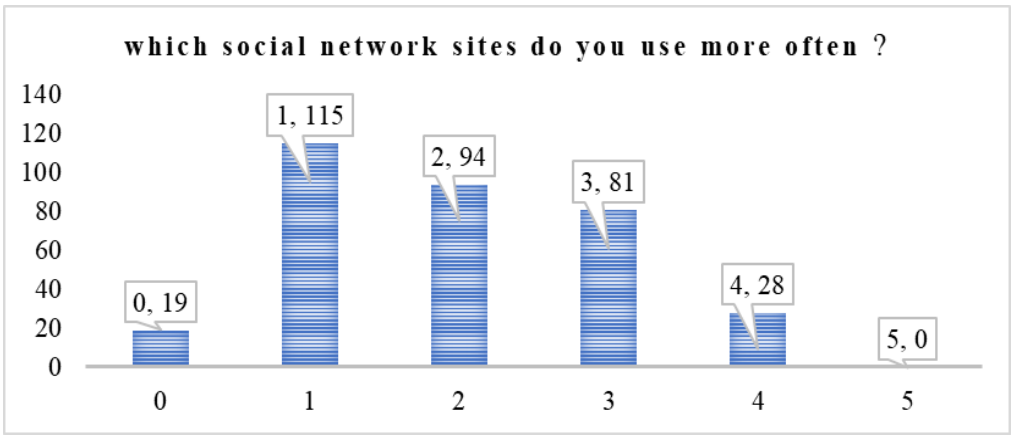

Fig 2

\section{Correlation Analysis}

Since the study have parametric data ,Pearson correlations are used to study the relationship between two continuous variables and the theoretical correlation coefficient is often expressed using the Greek letter rho ( $\rho$ ) (Lawrence's et.al.,2013).

\begin{tabular}{|c|c|c|c|c|c|c|c|c|c|c|c|c|}
\hline Variables & Mean & SD & INF & EN & DP & MA & VC & PE & I & IR & UA & ACB \\
\hline INF & 3.70 & .846 & 1 & & & & & & & & & \\
\hline EN & 3.83 & .904 & $.580^{* *}$ & 1 & & & & & & & & \\
\hline DP & 3.05 & .853 & $.161^{* *}$ & $.179^{* *}$ & 1 & & & & & & & \\
\hline MA & 3.34 & .932 & .088 & $.109^{*}$ & $.377^{* *}$ & 1 & & & & & & \\
\hline VC & 3.31 & .886 & .006 & .096 & $.322^{* *}$ & $.490^{* *}$ & 1 & & & & & \\
\hline PE & 3.71 & .920 & $.310^{* *}$ & $.394^{* *}$ & .066 & $.152^{* *}$ & .056 & 1 & & & & \\
\hline I & 3.08 & 1.088 & .059 & .088 & $.306^{* *}$ & $.334^{* *}$ & $.386^{* *}$ & .083 & 1 & & & \\
\hline IR & 2.60 & 1.030 & -.078 & -.012 & $.186^{* *}$ & .098 & $.189^{* *}$ & $.170^{* *}$ & $.368^{* *}$ & 1 & & \\
\hline UA & 3.41 & .543 & $.479^{* *}$ & $.527^{* *}$ & $.602^{* *}$ & $.602^{* *}$ & $.582^{* *}$ & $.404^{* *}$ & $.611^{* *}$ & $.295^{* *}$ & 1 & \\
\hline ACB & 3.29 & .508 & $.380^{* * *}$ & $.489^{* *}$ & $.574^{* *}$ & $.466^{* *}$ & $.551^{*}$ & $.316^{* *}$ & $.550^{* *}$ & $.469^{* *}$ & $.849^{* *}$ & 1 \\
\hline
\end{tabular}

Table 8:- Correlation Matrix

Correlation is significant at the 0.01 level (2tailed).Correlation is significant at the 0.05 level (2-tailed) Where $=\mathbf{I N F}=$ Informative, $\quad \mathbf{E N}=$ Entertaining, $\mathbf{D P}=$ Deceptive, $\mathbf{M A}=$ Materialism, $\mathbf{V C}=$ Value Corruption , $\mathbf{P E}=$ Promotes Economy, $\mathbf{I}=$ Intrusive, $\mathbf{I R}=$ Irritation, $\mathbf{U A}=$ User Attitudes, $\mathbf{A C B}=$ ad-clicking behavior

\section{Regression Analysis}

In order to analyze the relationships between dependent variables and independent variables Regression analysis, specifically a multiple regression is conducted to determine whether independent variables have a significant effect on dependent variables and to make predictions. Various data requirements have been taken into consideration before undertaking a regression analysis (Mooi et.al.2018). There are a number of assumptions which lie at the basis of the performance of a regression analysis. Failure to satisfy these assumptions makes the outcome of the analysis either less valid or invalidates it entirely and/or makes it unreliable. Accordingly, the following eight assumptions were checked under the study ( Wim Janssens .et al.2008) :

$>$ There was a causality present, whereby the dependent variable is explained by the independent variable(s) ( 
see the Annexed graph - regression standardized predictive Value )

$>$ All of the relevant (independent) variables were taken into consideration.

$>$ The dependent and independent variables are interval scaled (five-point Likert scale measurement were used for all variables)

$>$ There exists a linear relationship between the dependent and the independent variables ( see Annex -Normal P-P Plot of Regression Standardized Residual graph)

$>$ The residuals were checked and satisfy the following characteristics: (see in the annex regression standardized residual histogram graph)

- They are independent from one another.

- They are normally distributed.

- they have the same variance for each value of the independent variable (homoscedasticity assumption is satisfied)

- no relationship exists between the subsequent residuals

$>$ There is a sufficient number of observations in order to be able to provide a good indication of the 'fit'. The rule of thumb is at least five times as many observations as variables.
No multicollinearity observed : in other words, there was no high degree of correlation between the independent variables ( see Table 5 and Collinearity diagnostics table Annexed).

\section{E. Analysis Out put}

A Hierarchical linear regression analysis is used which is an extension of standard multiple linear regression, with a conceptual element resembling the step procedures. The key factor in hierarchical regression is that, in contrast to the step regression procedures where the researchers leave all decisions about entry to the software, the researchers play an active role in structuring the analysis within the hierarchical strategy where accordingly predictors are entered in order in subsets or blocks. In return for such an investment, researchers are able to statistically control for the effect of predictors when it makes theoretical, empirical, or common sense to do so. The primary advantage of using such a blocking or hierarchical strategy is that variables entered in earlier blocks serve as covariates for those entered later (Lawrence's et.al.,2013).

\begin{tabular}{|c|c|c|c|c|c|c|c|c|c|}
\hline \multirow[b]{2}{*}{ Model } & \multirow[b]{2}{*}{$\mathbf{R}$} & \multirow[b]{2}{*}{ R Square } & \multirow[b]{2}{*}{$\begin{array}{c}\text { Adjusted R } \\
\text { Square }\end{array}$} & \multirow[b]{2}{*}{$\begin{array}{c}\text { Std. Error of the } \\
\text { Estimate }\end{array}$} & \multicolumn{5}{|c|}{ Change Statistics } \\
\hline & & & & & $\begin{array}{l}\text { R Square } \\
\text { Change }\end{array}$ & F Change & df1 & df2 & $\begin{array}{c}\text { Sig. F } \\
\text { Change }\end{array}$ \\
\hline 1 & $.905^{\mathrm{a}}$ & .820 & .815 & .218 & .820 & 186.278 & 8 & 328 & .000 \\
\hline 2 & $.907^{b}$ & .822 & .817 & .217 & .002 & 4.206 & 1 & 327 & .041 \\
\hline
\end{tabular}

a. Predictors: (Constant), Irritation, Entertaining, Materialism, Deceptive, Promotes Economy, Intrusive, Value Corruption, Informative

b. Predictors: (Constant), Irritation, Entertaining, Materialism, Deceptive, Promotes Economy, Intrusive, Value Corruption, Informative, User Attitudes

Table 9:- Model Summary c

on $R$ Square and $R$ Square Change (and the tests of significance) associated with the three blocks and consequently the following results are noted; Thus 'Adjusted R Square' value differs significantly from zero, since the p-value from the 'ANOVA' table (Table 7 ) is less than .05. The model is therefore meaningful, and an interpretation of the regression coefficients is thus the next step; It appears from the Model Summary that in Block 1, Irritation, Entertaining, Materialism, Deceptive, Promotes Economy, Intrusive, Value Corruption, Informative accounted for a statistically significant quite large proportion $(81.5 \%)$ of the variance of ad-clicking behavior. From the Coefficients table, it is indicated that the variables are statistically significant $(\mathrm{p}<.000)$.

The addition of User Attitudes into the model in Block 2 made a relatively a very small improvement in the prediction ability of the model, accounting for an additional $81.7 \%$ of the variance of ad-clicking behavior. The prediction contribution of User Attitudes was statistically significant $(\mathrm{p}<.005)$ controlling for Irritation, Entertaining, Materialism, Deceptive, Promotes Economy, Intrusive, Value Corruption, Informative; at the same time, User Attitudes became the worst marginal predictor $(\mathrm{p}=$ .021 ), with the remaining predictors. there is a good fit between the model and the data, or, in other words, if this statistic differs significantly from zero.

Table 9 shows the result of model fit test and it showed that the multiple correlation $(\mathrm{R}$ is .907 , with a corresponding value of $\mathrm{R}$ Square of .822 , suggesting that $82.2 \%$ of the variance of ad-clicking behavior is explained by the set of independent variables implemented in the study. R Square Change is also .822, as all predictors were entered into the model in hierarchical step and similarly the Adjusted R Square value is .817, implicating that some R2 shrinkage occurred as a result of including eight predictors in the model. 
ISSN No:-2456-2165

\begin{tabular}{|c|c|c|c|c|c|c|}
\hline \multicolumn{2}{|r|}{ Model } & \multirow{2}{*}{$\begin{array}{c}\text { Sum of Squares } \\
71.007\end{array}$} & \multirow{2}{*}{\begin{tabular}{|c|} 
df \\
8
\end{tabular}} & \multirow{2}{*}{$\begin{array}{c}\text { Mean Square } \\
8.876\end{array}$} & \multirow{2}{*}{\begin{tabular}{c|}
$\mathbf{F}$ \\
186.278
\end{tabular}} & \multirow{2}{*}{$\begin{array}{l}\text { Sig. } \\
.000^{\mathrm{b}}\end{array}$} \\
\hline 1 & Regression & & & & & \\
\hline & Residual & 15.629 & 328 & .048 & & \\
\hline & Total & 86.636 & 336 & & & \\
\hline 2 & Regression & 71.205 & 9 & 7.912 & 167.666 & $.000^{\mathrm{c}}$ \\
\hline & Residual & 15.430 & 327 & .047 & & \\
\hline & Total & 86.636 & 336 & & & \\
\hline \multicolumn{7}{|c|}{ a. Dependent Variable: ad-clicking behavior } \\
\hline \multicolumn{7}{|c|}{$\begin{array}{c}\text { b. Predictors: (Constant), Irritation, Entertaining, Materialism, Deceptive, Promotes Economy, Intrusive, Value Corruption, } \\
\text { Informative }\end{array}$} \\
\hline
\end{tabular}

Table 10:- ANOVAa

\begin{tabular}{|c|c|c|c|c|c|c|c|}
\hline \multirow[b]{2}{*}{ Model } & \multicolumn{2}{|c|}{ Unstandardized Coefficients } & \multirow{2}{*}{$\begin{array}{c}\text { Standardized Coefficients } \\
\text { Beta } \\
\end{array}$} & \multirow[b]{2}{*}{$\mathbf{t}$} & \multirow[b]{2}{*}{ Sig. } & \multicolumn{2}{|c|}{ Collinearity Statistics } \\
\hline & B & Std. Error & & & & Tolerance & VIF \\
\hline (Constant) & .265 & .085 & & 3.111 & .002 & & \\
\hline Informative & .092 & 018 & .153 & 5.218 & .000 & .642 & 1.558 \\
\hline Entertaining & .135 & .017 & .240 & 7.923 & .000 & .599 & 1.668 \\
\hline Deceptive & .157 & .016 & .264 & 9.941 & .000 & .779 & 1.283 \\
\hline Materialism & .045 & .015 & .083 & 2.909 & .004 & .681 & 1.469 \\
\hline Value Corruption & .150 & .016 & .261 & 9.213 & .000 & .685 & 1.460 \\
\hline Promotes Economy & .096 & 015 & .174 & 6.564 & .000 & .787 & 1.271 \\
\hline Intrusive & .079 & .013 & .170 & 6.110 & .000 & .712 & 1.405 \\
\hline Irritation & .170 & .013 & .345 & 13.206 & .000 & .808 & 1.238 \\
\hline (Constant) & .267 & .085 & & 3.146 & .002 & & \\
\hline Informative & .068 & .021 & .112 & 3.201 & .002 & .441 & 2.267 \\
\hline Entertaining & .116 & .019 & .206 & 5.969 & .000 & .459 & 2.181 \\
\hline Deceptive & .132 & .020 & .222 & 6.649 & .000 & .488 & 2.050 \\
\hline Materialism & .025 & .018 & .046 & 1.359 & .175 & .483 & 2.069 \\
\hline Value Corruption & .127 & .020 & .222 & 6.497 & .000 & .468 & 2.138 \\
\hline Promotes Economy & .078 & .017 & .142 & 4.624 & .000 & .582 & 1.719 \\
\hline Intrusive & .057 & .017 & .123 & 3.429 & .001 & .423 & 2.362 \\
\hline Irritation & .159 & .014 & .322 & 11.375 & .000 & .681 & 1.468 \\
\hline User Attitudes & .159 & .077 & .170 & 2.051 & .041 & .080 & 12.567 \\
\hline
\end{tabular}

Table 11:- Coefficients ${ }^{\mathrm{a}}$

Table 10 presents the ANOVA summary table for each model and that the model with the two term is still statistically significant, even though the user attitudes term added no significant enhancement to the amount of variance that was explained but it is statistically significant because all the ten variables, which is doing all of the predictive work, are contained in the second model. 


\section{F. Hypothesis testing}

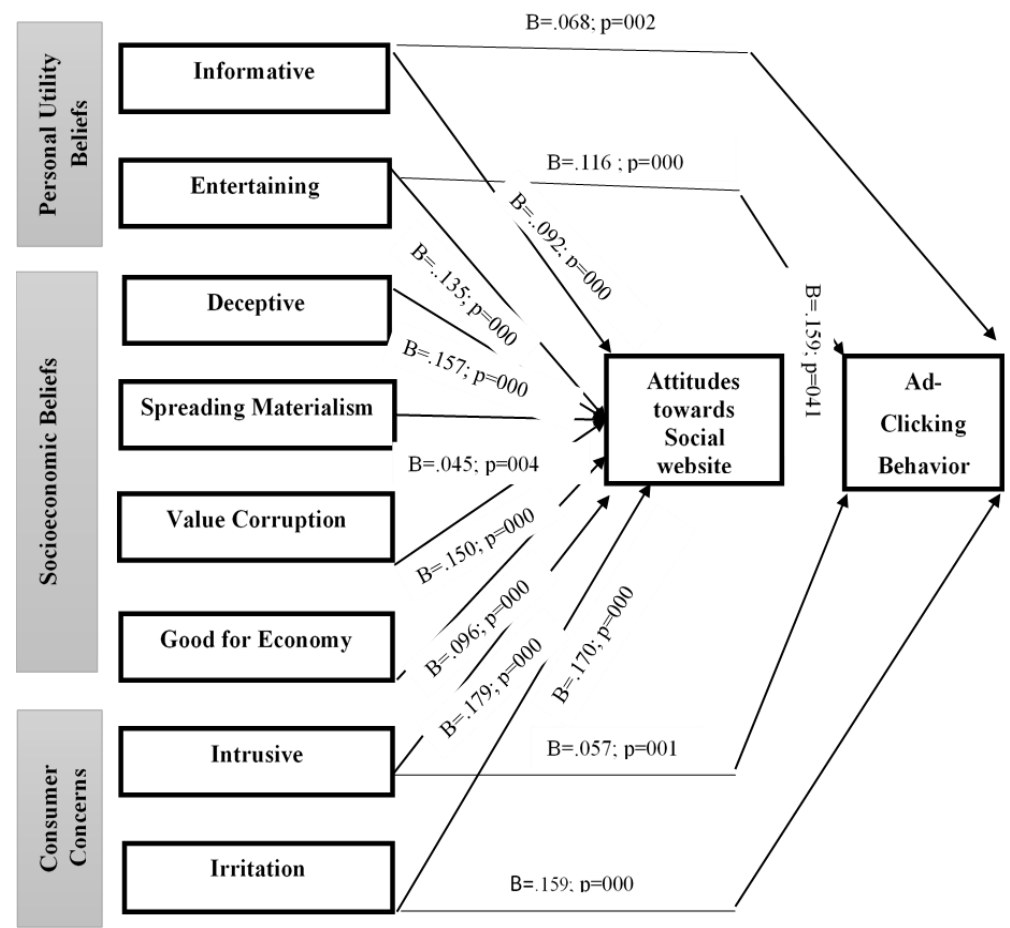

Fig 3

\begin{tabular}{|c|c|c|c|}
\hline Hypothesis & $\begin{array}{l}\text { Coefficients } \\
\text { (B) }\end{array}$ & Sig.(p) & Result \\
\hline $\begin{array}{l}\text { H1a. Personal utility Views of social websites advertising have a positive effect on } \\
\text { social websites users' attitudes toward social websites advertising. }\end{array}$ & $\begin{array}{l}\mathrm{B}=. .092 \\
\mathrm{~B}=.135\end{array}$ & $\begin{array}{l}\mathrm{p}=000 \\
\mathrm{p}=000\end{array}$ & Accepted \\
\hline $\begin{array}{l}\text { H1b. Personal utility Views of social websites advertising have a positive effect on } \\
\text { social websites users' ad-clicking behavior }\end{array}$ & $\begin{array}{l}\mathrm{B}=.068 \\
\mathrm{~B}=.116\end{array}$ & $\begin{array}{l}\mathrm{p}=002 \\
\mathrm{p}=000\end{array}$ & Accepted \\
\hline $\begin{array}{l}\text { H2a. Socioeconomic belief of social websites advertising as good for the economy } \\
\text { has a positive effect on social websites users' attitudes toward social websites } \\
\text { advertising. }\end{array}$ & $\mathrm{B}=.150$ & $\mathrm{p}=000$ & Accepted \\
\hline $\begin{array}{c}\text { H2b. Socioeconomic Views of social websites advertising as deceptive, } \\
\text { materialism and value corruption have negative effects on social websites users' ad- } \\
\text { clicking behavior. }\end{array}$ & $\begin{array}{l}\mathrm{B}=.135 \\
\mathrm{~B}=.157 \\
\mathrm{~B}=.045\end{array}$ & $\begin{array}{l}\mathrm{p}=000 \\
\mathrm{p}=000 \\
\mathrm{p}=004\end{array}$ & $\begin{array}{l}\text { Not } \\
\text { Accepted }\end{array}$ \\
\hline $\begin{array}{l}\text { H3a. Intrusiveness and irritation have a negative effect on social websites users' } \\
\text { attitudes toward social websites advertising . }\end{array}$ & $\begin{array}{l}\mathrm{B}=.179 \\
\mathrm{~B}=.170\end{array}$ & $\begin{array}{l}\mathrm{p}=000 \\
\mathrm{p}=000\end{array}$ & $\begin{array}{l}\text { Not } \\
\text { Accepted }\end{array}$ \\
\hline $\begin{array}{c}\text { H3b. Intrusiveness and irritation have a negative effect on social websites users' ad- } \\
\text { clicking behavior. }\end{array}$ & $\begin{array}{l}\mathrm{B}=.057 \\
\mathrm{~B}=.159\end{array}$ & $\begin{array}{l}\mathrm{p}=001 \\
\mathrm{p}=000\end{array}$ & $\begin{array}{l}\text { Not } \\
\text { Accepted }\end{array}$ \\
\hline $\begin{array}{l}\text { H4. Social websites users' attitudes toward social websites advertising have a } \\
\text { positive effect on their ad-clicking behavior. }\end{array}$ & $\mathrm{B}=.159$ & $\mathrm{p}=041$ & Accepted \\
\hline
\end{tabular}




\section{CONCLUSIONS \& RECOMMENDATIONS}

\section{A. Conclusions}

The present study finds that Ethiopian higher institution student consumers perceive about online social website sites as a multi-dimensional construct (i.e. Irritation, Entertaining, Materialism, Deceptive, Promotes Economy, Intrusive, Value Corruption, Informative,), and user attitudes as a one-dimensional construct result and the result found to be corresponds with previous findings of the literature (e.g. Wolin et al. 2002; Wang, Sun 2010b; Mahmoud 2012a, 2012b; Imran Mir,2015) indicating that the above stated factors play an important role in predicting Ethiopian higher institution student consumers ' attitudes towards their ad clicking behaviors .

Irritation and intrusiveness are found to exert a direct effect on Ethiopian higher institution student's behavior responses of leaving the website that presents the ads. Which implies that, if Ethiopian higher institution student encountered with a website that displays several ads, and those students will probably feel not confused and may still stay in the site, so students who perceive the ads as being irritating or confusing will probably be the drivers. The result further indicated that Ethiopian higher institution students stay with the website showing the ads, regardless of holding favorable or unfavorable affects towards social website advertising in general and this is a significant contribution to the current literature as beliefs could directly influence consumer behavioral responses towards social website advertising considering the fact that low internet penetration and awareness about online banner advertisement among Ethiopian society.

On a comparable note the study results also shows that entertainment directly influences Ethiopian higher institution students' reactions towards clicking on social website ads to obtain extra information related to the advertised product. Despite the fact that Ethiopian higher institution students hold positive attitudes towards social website advertising in general however, perceiving social website advertising as a source of entertainment (e.g. containing flash games) may predict Ethiopian higher institution students to click on online ads, Proving a direct relationship between entertainment and clicking on online ads, this demonstrates to the current literature that beliefs could be directly linked to behavior in Ethiopian higher institution student perspective. Attitudes towards online social website sites is found to mediate fully the relationship between all beliefs (i.e. information, irritation, good for economy and values corruption) and the behavioral response of clicking on internet ads in Ethiopian higher institution students perspective (Usman et al. 2010; Eze, Lee 2012; Zabadi et al. 2012; Kamal, Chu 2012b, Imran Mir,2015).

Moreover, attitudes are seen as completely mediate the relationship between entertainment and clicking on internet ads. This finding infers that Ethiopian higher institution students with positive beliefs about online advertising will probably form most likely frame good attitudes towards it and consequently improves the possibility of clicking on online advertisements. Also, Ethiopian higher institution students who like internet advertising all in all, will probably click on online ads, even if they describe those ads as entertaining or not.

The present study finds that the mediating power of the attitudes toward online social website sites advertising in general the relationship between beliefs (i.e. information, entertainment, and values corruption) and the behavioral response of leaving the website showing the ads (Shavitt et al. 1998; Wolin et al. 2002; Zhou, Bao 2002; Yang 2003; Wang, Sun 2010a, 2010b; Usman et al. 2010; Eze, Lee 2012; Zabadi et al. 2012; Kamal, Chu 2012b). In addition, the relationship between irritation and leaving the website showing ads will mediated partially by the attitude towards online social website sites advertising of users. That is, when Ethiopian higher institution students hold positive beliefs about online social website sites advertising, they may probably develop favorable affection and accordingly are less likely to leave a website with an advertising content this represents that with positive attitudes towards online SWA the students may probably keep navigating the website regardless of being irritated by online ads or not.

\section{B. Limitations of the Study}

The results of this study in regard to the relationships between beliefs, attitudes, and behaviors towards online social website sites advertising may need further investigation in cases of other electronic advertising medias to test the validity of the studies result across other means of advertisements in Ethiopian perspective. Furtherer more, the study sample is concentrate only on five private Higher institution found in the main capita city, Addis Ababa, further the study used a cross-sectional method and if all private and government higher institutions in Ethiopia were included and a longitudinal study was made a different outcome, which is may be different from the current study may have been obtained that may shed some light related with the Ethiopian higher institution student beliefs, attitudes, and behaviors towards online advertising clicking behavior.

\section{Recommendations}

In recent years Ethiopia has encountered quick development in internet usage and has increasingly become connected with the remainder of the world. As more advertisers incorporate new media, such as the internet, to reach international consumers, understanding Ethiopian consumers beliefs, attitudes, and behaviors towards online advertising clicking behavior will benefit global businesses since social marketing covers listening, discussing, interacting, empathizing, and engaging. Therefore today, marketing firms and brands requires to locate, identify, and participate in conversations with customers, potential customers and even critics from different parts of the world just by displaying ad that flashed brand messages to millions of users over a social websites who respond immediately, ask questions, or make observations that in turn lead a firm to be able to measure the success easily by identifying the number of unique visitors, and the number 
of "impressions" a marketing campaign generated .Advertising firms in Ethiopia are encouraged to influence Ethiopian students beliefs about online ads to be more positive may be by starting to exercise towards having social website advertising more informative (e.g. providing timely product-related information), more entertaining and engaging (e.g. including flash games within online ads, or enclosing amusing pictures) which currently is not professionally practiced.

Furthermore, even though the study respondents indicated that they are not irritated or found to be confused related with online ads accordingly the study recommended that online advertisers in Ethiopia to make their online ads less annoying and baffling (e.g. avoiding high volumes of ads within a website), and less values corruptive through improving targeting tools in a way for example that prevents kids from being exposed to improper ads (e.g. most social websites ads are accurately communicated to targeted segments of consumers) so that consumers will typically have more favorable friendliness and that leads to more favorable behavioral replies towards online ads in respect to click on them or the period of time that consumers spend online and exposed to them. All in all the current study found a positive association between Ethiopian private higher institution student users' attitudes toward advertising which appears on social website and their behavior to click on social website site banner ads indicating that Ethiopian private higher institution students social website users' have in general a positive attitudes toward social website advertising influence them to click on the banner ads appearing on social website.

\section{REFERENCES}

[1]. Aziz NA, Ariffin AAM (2010) Exploring Consumers' attitude towards web advertising and its influence on web ad usage in Malaysia. JournalPengurusan 31: 55-63.

[2]. Alwitt, L. F., \& Prabhaker, P. R. (1992). Functional and belief dimensions of attitudes to television advertising: Implications for copy testing. Journal of Advertising Research, 32(5), 30-42.

[3]. Azizul Yadi Yaakop (2011), attitudes towards advertising: malaysians vs. Non-malaysians, Asian Journal of Business and Management Sciences ISSN: 2047-2528 Vol. 1 No. 2 [77-94]

[4]. Azizul YadiYaakop, Marhana Mohamed Anuar,Khatijah Omar\& Alphonsus Liaw Kuok Liung (2011b), Consumers' Perceptions and Attitudes Towards Advertising on Facebooking Malaysia, December 2012SSRN Electronic Journal DOI: $10.2139 /$ ssrn.2183787

[5]. Amant, K.; Kelsey, S. (Ed.). Computer-Mediated Communication across Cultures: International Interactions in Online Environments. Hershey: PA: Information Science Reference

[6]. Ali Bassam Mahmoud,(2013) Syrian Consumers: Beliefs, Attitudes, And Behavioral Responses to Internet Advertising, Verslas: Teorija ir praktika
Business: Theory and Practice Issn 1648-0627 print / Issn 1822-4202 online

[7]. Boyd DM, Ellison NB (2007) Social network sites: Definition, history, and scholarship. Journal of Computer-Mediated Communication 13: 210-230.

[8]. Baek TH, Morimoto M (2012) Stay Away from me: Examining the determinants of consumer avoidance of personalized advertising. Journal of Advertising 41: 59-76.

[9]. Bambauer-Sachse, S., \& Mangold, S. (2011). Brand equity dilution through negative online word-ofmouth communication. Journal of Retailing and Consumer Services, 18(1), 38-45. Li, C., \& Bernoff, J. (2011). Groundswell: Winning in a world transformed by social technologies. Boston: Harvard Business Review Press.

[10]. Boardman, R., \& McCormick, H. (2018). Shopping channel preference and usage motivations: Exploring differences amongst a 50-year age span. Journal of Fashion Marketing and Management: An International Journal, 22(2), 270-284.

[11]. Christodoulides, G., Michaelidou, N., \& Siamagka, N. (2013). A typology of internet users based on comparative affective states: Evidence from eight countries. European Journal of Marketing, 47(1/2), 153-173.

[12]. Constantinides E, Fountain SJ (2008) Web 2.0: Conceptual foundations and marketing issues. Journal of Direct, Data and Digital Marketing Practice 9: 231-244.

[13]. Cui, Y., \& Roto, V. (2008). How People Use the Web on Mobile Devices. In. 17th International World Wide Web Conferenc, April 21-25, 2008, Beijing, China.

[14]. Cooper, Donald R.,2014, Business Research Methods, Twelfth Edition, Published by McGrawHill/Irwin, a business unit of The McGraw-Hill Companies, Inc., 1221 Avenue of the Americas, New York, NY, 10020. ISBN 978-0-07-352150-3.

[15]. Chatterjee P, Hoffman DL, Novak TP (2003) Modeling the clickstream: Implications for webbased advertising efforts. Marketing Science 22: 520- 541.

[16]. Cho CH (1999), How advertising works on the www: Modified elaboration

[17]. Chandon JL, Chtourou MS, Fortin DR (2003) Effects of configuration and exposure levels on responses to web advertisements. Journal of Advertising Research 43: 217-29.

[18]. Constantinides E, Fountain SJ (2008) Web 2.0: Conceptual foundations and marketing issues. Journal of Direct, Data and Digital Marketing Practice 9: 231-244.

[19]. Diffley S, Kearns J, Bennett W, Kawalek P (2011) Consumer behavior in social networking sites: Implications for marketers. Irish Journal of Management 30: 47-65.

[20]. Ducoffe RH (1996) Advertising value and advertising on the web. Journal of Advertising Research 36: 21-35. 
[21]. Darren George and Paul Mallery, (2019), IBM SPSS Statistics 25 Step by Step, A Simple Guide and Reference ,15th edition. published 2019 by Routledge , New York, NY 10017 ISBN: 978-1351-03390-9 (ebk).

[22]. Darke PR, Ritchie RJB (2007), The defensive consumer: advertising deception, defensive processing, and distrust. Journal of Marketing Research 114-127.

[23]. Demerling, R.S. (2010). Twitter me this, Twitter me that. The Marketization of Brands through Social Networking Sites. Stream: Culture/Politics/Technolog y, 3(1), 33-46.

[24]. Daniel A. Ackerberg, (2003),Advertising, learning, and consumer choice in experience good markets: an empirical examination, international economic review, Volume44, Issue3, Pages 1007-1040 https://doi.org/10.1111/1468-2354.t01-2-00098

[25]. Doherty, N., \& Delener, N. (2001). Chaos theory: Marketing \& management implications. Journal of Marketing Theory and Practice, 9(4), 66-75.

[26]. eMarketer, Inc. (July 2019) "global-social-networkusers, 2020.”. available at https://www.emarketer.com/content/global-socialnetwork-users

[27]. Eze UC, Lee CH (2012) Consumers' attitude towards advertising. International Journal of Business and Management 7: 94-108. Research 36: 21-35.

[28]. Eagleman, A.N. (2013). Acceptance, Motivations, and Usage of Social Media as a Marketing Communications Tool amongst Employees of Sport National Governing Bodies. Sport Management Review, 16(4), 488-497.

[29]. Edwards,S.M. (2011).A Social Media Mindset. Journal of Interactive Advertising, 12(1),1-3.

[30]. Engel, J.F., Blackwell, R.D., \& Miniard, P.W. (1995). Consumer Behavior ,Fort Worth, TX: Dryden.

[31]. Esfahani, F., Sardar, M.A., \& Kashani, B.M. (2012). Relationship between Media Advertisements and Purchase of Losing Weight Sport Products in Iran. World Applied Sciences Journal, 17(7), 821-825.

[32]. Fishbein M, Ajzen I (1975) Belief, attitude, intention and behavior: An Introduction to Theory and Research. Addison-Wesley, Reading, MA 10: 130- 132.

[33]. Fraser, M., \& Dutta, S. (2008). Throwing sheep in the boardroom: How online social networking will transform your life, work, and world. Hoboken: Wiley

[34]. Goldsmith, R.E. (2005), Online Consumer Behavior. In Subhasish Dasgupta (Ed.), The Encyclopedia of Virtual Communities and Technologies, Hershey, PA: Idea Group Publishing, pp. 338-342.

[35]. Glenn D. Israel,(2013) Determining Sample Size, Institute of Food and Agricultural Sciences (IFAS), University of Florida, Gainesville 32611,PP2-4

[36]. GSM (2019), The Mobile Economy, Sub-Saharan Africa 2019.abialable at www.gsmaintelligence.com
[37]. Grizane, T., \& Jurgelane, I. (2017). Social media impact on business evaluation. Procedia Computer Science, 104, 190-196.

[38]. Goodrich, K. (2013). Effects of age and time of day on internet advertising outcomes. Journal of Marketing Communications, 19(4), 229-244.

[39]. Hadija Z, Barnes SB, Hair N (2012) Why we ignore social networking advertising. Qualitative Market Research: An International Journal 15: 19-32.

[40]. Hofacker CF, Murphy J (1998) World Wide Web banner advertisement copy testing. European Journal of Marketing 32: 703-712.

[41]. He, W., Wang, F. K., Chen, Y., \& Zha, S. (2017). An exploratory investigation of social media adoption by small businesses. Information Technology and Management, 18(2), 149-160.

[42]. Imran Mir,(2015) Effects of Beliefs and Concerns on User Attitudes toward Online Social Network Advertising and Their Ad Clicking Behavior, Journal of Internet Banking and Commerce, An open access Internet journal August 2015, vol. 20, no. 2

[43]. John W. Creswell (2014), Research design :qualitative, quantitative, and mixed methods approach 4th ed, SAGE Publications, Inc. 2455 Teller Road Thousand Oaks, California 91320, ISBN 978-1-4522-2609-5

[44]. Jones, M., 1999. Entertaining shopping experiences: an exploratory investigation. Journal of Retailing and Consumer Services.

[45]. Morteza Jamalzadeh, Navid Behravan,\& Roozbeh Masoudi (2012), An Empirical Study of EmailBased Advertisement and its Influence on Consumers' Attitude, International Review of Management and Marketing Vol. 2, No. 3, 2012, pp.130-138 ISSN: 2146-4405

[46]. Kiesler, Sara. (January-February1986). "The Hidden Messages in Computer Networks." Harvard Business Review.

[47]. Kiesler, Sara, Jane Siegel, and Timothy W. McGuire. (October 1984). "Social Psychological Aspects of Computer-Mediated Communication." American Psychologist

[48]. Kaplan AM, Haenlein M (2010) Users of the world, unite! The challenges and opportunities of social media. Business Horizons 53: 59-68.

[49]. Kelly L, Kerr G, Drennan J (2010) Avoidance of advertising in social networking sites: The teenage perspective. Journal of Interactive Advertising 10: 16-27.

[50]. Korgaonkar P, Silverblatt R, O’Leary B (2001) Web advertising and Hispanics. Journal of Consumer Marketing 18: 134-152.

[51]. Kozel R., Klézl V., \& Pawlasová P. (2013). The Verification of Structural Decision-Making Model for Evaluating Education on Facebook. Journal of Competitiveness, 5(3), 76-89.

[52]. Karlíček, M., Tomek, I., Hasprová, M., \& Zamazalová, M. (2012), Social Network Sites in the Czech Republic: An Empirical Study. Management \& Marketing, 7(1), 15-28. 
[53]. Kwek Choon Ling, Tan Hoi Piew,\& Lau Teck Chai, The Determinants of Consumers' Attitude Towards Advertising, canadian social science vol. 6, no. 4, 2010, pp. 114-126, SSN 1712-8056

[54]. Kamal, S.; Chu, S. 2012a. Cultural differences in social media usage and beliefs and attitudes towards advertising on social media: findings from Dubai, United Arab Emirates, in St.

[55]. Kenneth C. Laudon and Carol Guercio Traver (2018), E-commerce 2017: business, technology, society 13th edition Identifiers, Boston: Pearson: LCCN 2016035789| ISBN 9780134601564 | ISBN 0134601564

[56]. Kaplan, A. M., \& Haenlein, M. (2010). Users of the world unite! The challenges and opportunities of social media. Business Horizon, 53, 59-68.

[57]. Keller, K. L. (2009). Managing the growth tradeoff: Challenges and opportunities in luxury branding. Journal of Brand Management, 16(5-6), 290-301.

[58]. Kuo, H., Chen, C., \& Hsu, C. (2012). A study of a B2C supporting interface design system for the elderly. Human Factors and Ergonomics in Manufacturing \& Service Industries, 22(6), 528540.

[59]. Kwon, W., \& Noh, M. (2010). The influence of prior experience and age on mature consumers' perceptions and intentions of internet apparel shopping. Journal of Fashion Marketing and Management, 14(3), 335-349.

[60]. Keller, K. L. (2009). Managing the growth tradeoff: Challenges and opportunities in luxury branding. Journal of Brand Management, 16(5-6), 290-301.

[61]. Kuo, H., Chen, C., \& Hsu, C. (2012). A study of a B2C supporting interface design system for the elderly. Human Factors and Ergonomics in Manufacturing \& Service Industries, 22(6), 528540.

[62]. Kwon, W., \& Noh, M. (2010). The influence of prior experience and age on mature consumers' perceptions and intentions of internet apparel shopping. Journal of Fashion Marketing and Management, 14(3), 335-349.

[63]. Li H, Edwards SM, Lee JH (2002) Measuring the intrusiveness of advertisements: Scale development and validation. Journal of Advertising 31:

[64]. Lawerences mayres,Glennc.Gamst,A.G. Guriano ,9 2013) Performing data analysis using IBM SPSS. Copyright (C) 2013 by John Wiley \& Sons, Inc. Published by John Wiley \& Sons, Inc., Hoboken, New Jersey.

[65]. Lin, X., Li, Y., \& Wang, X. (2017). Social commerce research: Definition, research themes and the trends. International Journal of Information Management, 37, 190-121

[66]. Morrow, M. (2014). Social media: Staying connected. Nursing Science Quarterly, 27(4), 340340.

[67]. Mintel Reports. (2018). Social and media networks - UK - May 2018. Available at: http://academic.mintel.com/display/859203/
[68]. Mangold, W. G. W., \& Faulds, D. D. J. (2009). Social media: The new hybrid element of the promotion mix. Business Horizons, 52(4), 357-365.

[69]. Mahmoud, A. B. 2012a. The role of gender in Syrian consumers' beliefs about and attitudes towards online advertising, European Journal of Economics, Finance and Administrative Sciences (47): 90-99.

[70]. Mir I, Zaheer A (2012), Verification of social impact theory claims in social media context. Journal of Internet Banking and Commerce 17: 1.

[71]. Mittal B (1994) ,Public assessment of TV advertising: Faint praise and harsh criticism. Journal of Advertising Research 34: 35-53.

[72]. McCoy S, Everard A, Polak P, Galletta DF (2008), An experimental study of antecedents and consequences of online ad intrusiveness. International Journal of Human-Computer Interaction 24: 672-699

[73]. Nan X (2006), Perceptual predictors of global attitude toward advertising: An investigation of both generalized and personalized beliefs. Journal of Current Issues and Research in Advertising 28: 31 44.

[74]. Neti, S. (2011), Social Media and its Role in Marketing; International Journal of Enterprise Computing and Business Systems, 1(2), 1-15.

[75]. National bank of Ethiopia( 2019), Annual report for the year 2018/19,Avavialable at https://nbebank.com/annual-report/

[76]. Punj, G.N., \& Staelin, R. (1983). A Model of Consumer Information Search for New Automobiles; Journal of Consumer Research, 9(4), 366-380.

[77]. Park, N., Kee, K.F., \& Valenzuela, S. (2009). Being Immersed in Social Networking Environment: Facebook Groups, Uses and Gratifications, and Social Outcomes; Cyberpsycholog y \& Behavior, 12(6), 729-733.

[78]. Phua, J., Jin, S. V., \& Kim, J. (2017). Gratifications of using Facebook, Twitter, Instagram, or SWApchat to follow brands: The moderating effect of social comparison, trust, tie strength, and network homophily on brand identification, brand engagement, brand commitment, and membership intention. Telematics and Informatics, 34(1), 412424.

[79]. Petrovici D, Marinov M (2007) Determinants and antecedents of general attitudes towards advertising: A Study of two EU accession countries, European Journal of Marketing 41: 307-326.

[80]. Pollay RW, Mittal B (1993) ,Here's the beef: Factors, determinants, and segments in consumer criticism of advertising. Journal of Marketing 57: 99- 114.

[81]. Petrovici D, Paliwoda S (2007), An empirical examination of public attitudes towards advertising in a transitional economy. International Journal of Advertising 26: 247-276. 
[82]. Polak EL, Mccullough ME (2006) ,Is gratitude an alternative to materialism Journal of Happiness Studies 7:343-360.

[83]. Pollay RW (1986), The distorted mirror: Reflections on the unintended consequences of advertising. Journal of Marketing 50: 18-36

[84]. Pavlou PA, Stewart DW (2000), Measuring the effects and effectiveness of interactive advertising: A research agenda. Journal of Interactive Advertising 1: 62-78.

[85]. Rheingold, Howard(1993), The Virtual Community. Cambridge MA: MIT Press

[86]. Roberts KK (2010) ,Privacy and perceptions: How Facebook advertising affects its users. The Elon Journal of Undergraduate Research in Communications 1: 24-34.

[87]. Saeedi TA (2012) E-Commerce Money matters

[88]. Senn, J. A. (2000). The emergence of m-commerce. Computer, 33(12), 148-150.

[89]. Sim E, Habel C (2011) ,Get out of Myspace: Exploring perceptions of intrusiveness in social media advertising, ANZMAC.

[90]. Steven M. Edward, Hairong Li,Joo-Hyun Lee (2013). Measuring the Intrusiveness of Advertisements: Scale Development and Validation, Journal of Advertising Volume 31, 2002 - Issue 2

[91]. Scott, D. M. (2015). The new rules of marketing \& PR: How to use social media, online video, mobile applications, blogs, news releases, and viral marketing to reach buyers directly. Hoboken: Wiley.

[92]. Taylor, M., \& Kent, M. (2014). The value of social media for pushing activist organizations social agendas: Implications for PR theory and practice. Quarterly Journal of Business Disciplines, 1(1), 7687.

[93]. Tiago, M. T., \& Veríssimo, J. M. C. (2014). Digital marketing and social media: Why bother? Business Horizons, 57(6), 703-708.

[94]. Taylor DG, Lewin JE, Strutton D (2011) Friends, fans, and followers: Do ads work on social networks How gender and age shape receptivity. Journal of Advertising Research 51: 258-275.

[95]. T. C. Srinivasan (1987), "An Integrative Approach to Consumer Choice", in NA - Advances in Consumer Research Volume 14, eds. Melanie Wallendorf and Paul Anderson, Provo, UT : Association for Consumer Research, Pages: 96-100.

[96]. SJ, Chia L (2007), Are we measuring the same attitude Understanding media effects on attitude towards advertising. Marketing Theory 7: 353-377.
[97]. Truonga Y, Simmons G (2010) Perceived intrusiveness in digital advertising: strategic marketing implications. Journal of Strategic Marketing 18: 239-256.

[98]. Usman, M.; Ilyas, S.; Hussain, M. F. 2010. General attitude towards advertising: cultural influence in Pakistan, International Journal of Marketing Studies 2(2): 124-133.

[99]. Vasalou, A., Joinson, A.N., \& Courvoisier, D. (2010). Cultural Differences, Experience with Social Networks, and the Nature of "True Commitment" in Facebook. International Journal of HumanComputer Studies, 68(10), 719-728.

[100]. Wang Y, Sun S (2010) Assessing beliefs, attitudes, and behavioral responses toward online advertising in three countries. International Business Review 19: 333-344.

[101]. Wolin LD, Korgaonkar P, Lund D (2002) Beliefs, attitudes, and behavior towards web advertising. International Journal of Advertising 21: 87-113.

[102]. Wim Janssens, Katrien Wijnen,Patrick De Pelsmacker,Patrick Van Kenhove(2008), Marketing research with SPSS, (C) Pearson Education Limited 2008, ISBN: 978-0-273-70383-9

[103]. Wolin, L. D.; Korgaonkar, P. 2005. Web advertising: gender differences in beliefs, attitudes, and behavior, Journal of Interactive Advertising 6(1): 125-136.

[104]. Wang, Y.; Sun, S. 2010b. Examining the role of beliefs and attitudes in online advertising: A comparison between the USA and Romania, International Marketing Review 27(1): 87-107.

[105]. Yang CC (2000) Taiwanese students' attitudes towards and beliefs about advertising. Journal of Marketing Communications 6: 171-183.

[106]. Ying L, Korneliussen T, Gronhaug K (2009) ; The effect of ad value, ad placement and ad execution on the perceived intrusiveness of web advertisements. International Journal of Advertising 28: 623-638.

[107]. Yadav, M., \& Rahman, Z. (2017). Measuring consumer perception of social media marketing activities in e-commerce industry: Scale development and validation. Telematics and Informatics, 34(7), 1294-1307.

[108]. Zimerman, M. (2012). Digital natives, searching behavior and the library. New Library World, 113(3/4), 174-201. 


\section{ANNEX}

\begin{tabular}{|c|c|c|}
\hline \multicolumn{3}{|c|}{ Communalities } \\
\hline Informative1 & Initial & Extraction \\
\hline Informative2 & 1.000 & .705 \\
\hline Informative3 & 1.000 & .683 \\
\hline Entertaining1 & 1.000 & .610 \\
\hline Entertaining2 & 1.000 & .724 \\
\hline Entertaining3 & 1.000 & .707 \\
\hline Deceptive1 & 1.000 & .673 \\
\hline Deceptive2 & 1.000 & .685 \\
\hline Deceptive3 & 1.000 & .727 \\
\hline Deceptive4 & 1.000 & .690 \\
\hline Materialism1 & 1.000 & .516 \\
\hline Materialism2 & 1.000 & .747 \\
\hline Materialism3 & 1.000 & .578 \\
\hline ValueCorruption1 & 1.000 & .603 \\
\hline ValueCorruption2 & 1.000 & .781 \\
\hline ValueCorruption3 & 1.000 & .790 \\
\hline PromotesEconomy1 & 1.000 & .665 \\
\hline PromotesEconomy2 & 1.000 & .766 \\
\hline Intrusive1 & 1.000 & .782 \\
\hline Intrusive2 & 1.000 & .839 \\
\hline Intrusive3 & 1.000 & .747 \\
\hline Irritation1 & 1.000 & .799 \\
\hline Irritation2 & 1.000 & .824 \\
\hline Irritation3 & 1.000 & Cxtraction Method: Principal Component Analysis \\
\hline
\end{tabular}

Table 13

\begin{tabular}{|c|c|}
\hline \multicolumn{2}{|c|}{ Reliability Statistics } \\
\hline Cronbach's Alpha & N of Items \\
\hline .772 & 10 \\
\hline
\end{tabular}

Table 14

\begin{tabular}{|c|c|c|c|c|}
\hline \multicolumn{5}{|c|}{ Item-Total Statistics } \\
\hline & $\begin{array}{c}\text { Scale Mean if Item } \\
\text { Deleted }\end{array}$ & $\begin{array}{c}\text { Scale Variance if Item } \\
\text { Deleted }\end{array}$ & $\begin{array}{c}\text { Corrected Item- } \\
\text { Total Correlation }\end{array}$ & $\begin{array}{c}\text { Cronbach's Alpha if } \\
\text { Item Deleted }\end{array}$ \\
\hline Informative & 29.62 & 21.568 & .317 & .768 \\
\hline Entertaining & 29.49 & 20.679 & .398 & .758 \\
\hline Deceptive & 30.27 & 20.399 & .473 & .748 \\
\hline Materialism & 29.98 & 19.999 & .468 & .749 \\
\hline ValueCorruption & 30.01 & 20.290 & .463 & .750 \\
\hline PromotesEconomy & 29.61 & 21.791 & .249 & .779 \\
\hline Intrusive & 30.24 & 19.000 & .484 & .748 \\
\hline Initation & 30.72 & 21.685 & .211 & .788 \\
\hline User Attitudes & 29.91 & 19.873 & .952 & .714 \\
\hline adclickingbehavior & 30.03 & 20.441 & .887 & .723 \\
\hline
\end{tabular}

Table 15 


\section{Total Variance Explained}

\begin{tabular}{|c|c|c|c|c|c|c|c|c|c|c|}
\hline \multirow[b]{2}{*}{ Component } & \multicolumn{3}{|c|}{ Initial Eigenvalues } & \multicolumn{3}{|c|}{ Extraction Sums of Squared Loadings } & \multicolumn{4}{|c|}{ Rotation Sums of Squared Loadings } \\
\hline & Total & $\begin{array}{c}\% \text { of } \\
\text { Variance }\end{array}$ & Cumulative \% & Total & $\%$ of Variance & Cumulative $\%$ & Total & $\begin{array}{c}\% \text { of } \\
\text { Variance }\end{array}$ & \multicolumn{2}{|c|}{ Cumulative $\%$} \\
\hline 1 & 5.131 & 21.379 & 21.379 & 5.131 & 21.379 & 21.379 & 3.631 & 15.128 & \multicolumn{2}{|c|}{15.128} \\
\hline 2 & 3.943 & 16.429 & 37.808 & 3.943 & 16.429 & 37.808 & 2.730 & 11.375 & & 503 \\
\hline 3 & 2.239 & 9.328 & 47.136 & 2.239 & 9.328 & 47.136 & 2.677 & 11.154 & & 557 \\
\hline 4 & 1.703 & 7.096 & 54.232 & 1.703 & 7.096 & 54.232 & 2.252 & 9.381 & & 38 \\
\hline 5 & 1.605 & 6.688 & 60.920 & 1.605 & 6.688 & 60.920 & 2.193 & 9.137 & & 176 \\
\hline 6 & 1.212 & 5.051 & 65.970 & 1.212 & 5.051 & 65.970 & 1.752 & 7.301 & & 477 \\
\hline 7 & 1.113 & 4.638 & 70.608 & 1.113 & 4.638 & 70.608 & 1.711 & 7.131 & & 508 \\
\hline 8 & .919 & 3.830 & 74.438 & & & & & & & \\
\hline 9 & .799 & 3.327 & 77.765 & & & & & & & \\
\hline 10 & .664 & 2.768 & 80.534 & & & & & & & \\
\hline 11 & .603 & 2.511 & 83.045 & & & & & & & \\
\hline 12 & .537 & 2.238 & 85.283 & & & & & & & \\
\hline 13 & .455 & 1.895 & 87.177 & & & & & & & \\
\hline 14 & .446 & 1.859 & 89.036 & & & & & & & \\
\hline 15 & .398 & 1.658 & 90.694 & & & & & & & \\
\hline 16 & .372 & 1.550 & 92.244 & & & & & & & \\
\hline 17 & .356 & 1.482 & 93.726 & & & & & & & \\
\hline 18 & .313 & 1.302 & 95.028 & & & & & & & \\
\hline 19 & .266 & 1.110 & 96.138 & & & & & & & \\
\hline 20 & .252 & 1.049 & 97.188 & & & & & & & \\
\hline 21 & .222 & .925 & 98.113 & & & & & & & \\
\hline 22 & .181 & .754 & 98.867 & & & & & & & \\
\hline 23 & .142 & .590 & 99.457 & & & & & & & \\
\hline 24 & .130 & .543 & 100.000 & & & & & & & \\
\hline & & & & xtraction & od: Principal Co & t Analysis. & & & & \\
\hline & & & & & ted Component $\mathrm{I}$ & & & & & \\
\hline & & & & & & mponent & & & & \\
\hline & & & 1 & 2 & 3 & 4 & 5 & & 6 & 7 \\
\hline & ative2 & & 796 & & & & & & & \\
\hline & ative1 & & 793 & & & & & & & \\
\hline & aining1 & & 772 & & & & & & & \\
\hline & ative3 & & 764 & & & & & & & \\
\hline & aining2 & & 724 & & & & & & & \\
\hline & aining3 & & 693 & & & & & & & \\
\hline & sive2 & & & 83 & & & & & & \\
\hline & sive1 & & & 37 & & & & & & \\
\hline & sive3 & & & 89 & & & & & & \\
\hline & ion3 & & & & .883 & & & & & \\
\hline & ion1 & & & & .871 & & & & & \\
\hline & ion2 & & & & .834 & & & & & \\
\hline & tive4 & & & & .433 & & .405 & & & \\
\hline & alism1 & & & & & .835 & & & & \\
\hline & alism3 & & & & & .673 & & & & \\
\hline & alism2 & & & & & .634 & & & & \\
\hline Valu & ruption3 & & & & & .511 & & & & \\
\hline & tive2 & & & & & & .827 & & & \\
\hline & tive3 & & & & & & .761 & & & \\
\hline & tive1 & & & & & & .758 & & & \\
\hline Valu & ruption1 & & & & & & & & 41 & \\
\hline Valu & rruption2 & & & & & & & & 22 & \\
\hline Promc & Economy2 & & & & & & & & & .783 \\
\hline Promc & conomy1 & & & & & & & & & .779 \\
\hline & & & $\begin{array}{r}\text { Ex } \\
\text { Rota }\end{array}$ & $\begin{array}{l}\text { tracti } \\
\text { ation I }\end{array}$ & $\begin{array}{l}\text { Principal } \\
\text { imax with }\end{array}$ & $\begin{array}{l}\text { t Analysis. } \\
\text { rmalization. }\end{array}$ & & & & \\
\hline
\end{tabular}


ISSN No:-2456-2165

\begin{tabular}{|c|c|c|c|c|c|c|c|c|c|c|c|c|c|}
\hline \multicolumn{14}{|c|}{ Collinearity Diagnostics $^{a}$} \\
\hline \multirow[b]{2}{*}{$\begin{array}{c}\text { Mod } \\
\text { el }\end{array}$} & \multirow[b]{2}{*}{$\begin{array}{c}\text { Dimensi } \\
\text { on }\end{array}$} & \multirow[b]{2}{*}{$\begin{array}{l}\text { Eigenva } \\
\text { lue }\end{array}$} & \multirow{2}{*}{$\begin{array}{c}\text { Conditi } \\
\text { on } \\
\text { Index }\end{array}$} & \multicolumn{10}{|c|}{ Variance Proportions } \\
\hline & & & & $\begin{array}{c}\text { (Consta } \\
\mathrm{nt})\end{array}$ & $\begin{array}{l}\text { Informat } \\
\text { ive }\end{array}$ & $\begin{array}{c}\text { Entertain } \\
\text { ing }\end{array}$ & $\begin{array}{c}\text { Decepti } \\
\text { ve }\end{array}$ & $\begin{array}{l}\text { Materiali } \\
\text { sm }\end{array}$ & $\begin{array}{c}\text { ValueCorrup } \\
\text { tion }\end{array}$ & $\begin{array}{c}\text { PromotesEcon } \\
\text { omy }\end{array}$ & $\begin{array}{l}\text { Intrusi } \\
\text { ve }\end{array}$ & $\begin{array}{l}\text { Irritati } \\
\text { on }\end{array}$ & $\begin{array}{c}\text { UserAttitu } \\
\text { des }\end{array}$ \\
\hline \multirow[t]{9}{*}{1} & 1 & 8.535 & 1.000 & .00 & .00 & .00 & .00 & .00 & .00 & .00 & .00 & .00 & \\
\hline & 2 & .151 & 7.518 & .00 & .02 & .02 & .00 & .00 & .00 & .04 & .07 & .37 & \\
\hline & 3 & .090 & 9.728 & .00 & .03 & .03 & .02 & .11 & .07 & .01 & .10 & .36 & \\
\hline & 4 & .064 & 11.589 & .00 & .00 & .00 & .14 & .07 & .03 & .04 & .75 & .06 & \\
\hline & 5 & .050 & 13.041 & .00 & .02 & .00 & .66 & .08 & .13 & .08 & .06 & .04 & \\
\hline & 6 & .038 & 15.011 & .00 & .12 & .09 & .08 & .04 & .25 & .53 & .00 & .03 & \\
\hline & 7 & .034 & 15.818 & .00 & .08 & .00 & .08 & .67 & .40 & .11 & .01 & .01 & \\
\hline & 8 & .022 & 19.665 & .14 & .39 & .79 & .00 & .02 & .00 & .00 & .00 & .01 & \\
\hline & 9 & .016 & 23.359 & .84 & .34 & .06 & .01 & .00 & .11 & .19 & .01 & .12 & \\
\hline \multirow[t]{10}{*}{2} & 1 & 9.533 & 1.000 & .00 & .00 & .00 & .00 & .00 & .00 & .00 & .00 & .00 & .00 \\
\hline & 2 & .151 & 7.938 & .00 & .01 & .01 & .00 & .00 & .00 & .03 & .04 & .32 & .00 \\
\hline & 3 & .090 & 10.270 & .00 & .02 & .02 & .01 & .08 & .05 & .01 & .06 & .30 & .00 \\
\hline & 4 & .064 & 12.246 & .00 & .00 & .00 & .09 & .05 & .02 & .03 & .45 & .05 & .00 \\
\hline & 5 & .050 & 13.772 & .00 & .01 & .00 & .41 & .06 & .09 & .06 & .03 & .04 & .00 \\
\hline & 6 & .038 & 15.856 & .00 & .08 & .06 & .05 & .03 & .17 & .39 & .00 & .03 & .00 \\
\hline & 7 & .034 & 16.716 & .00 & .05 & .00 & .05 & .48 & .28 & .08 & .00 & .01 & .00 \\
\hline & 8 & .022 & 20.767 & .15 & .27 & .59 & .00 & .01 & .00 & .00 & .00 & .01 & .00 \\
\hline & 9 & .016 & 24.520 & .83 & .21 & .06 & .00 & .00 & .06 & .13 & .01 & .09 & .00 \\
\hline & 10 & .002 & 74.603 & .00 & .33 & .24 & .38 & .29 & .33 & .27 & .41 & .16 & 1.00 \\
\hline & & & & & & & & isi & ivior & & & & \\
\hline
\end{tabular}

Table 16

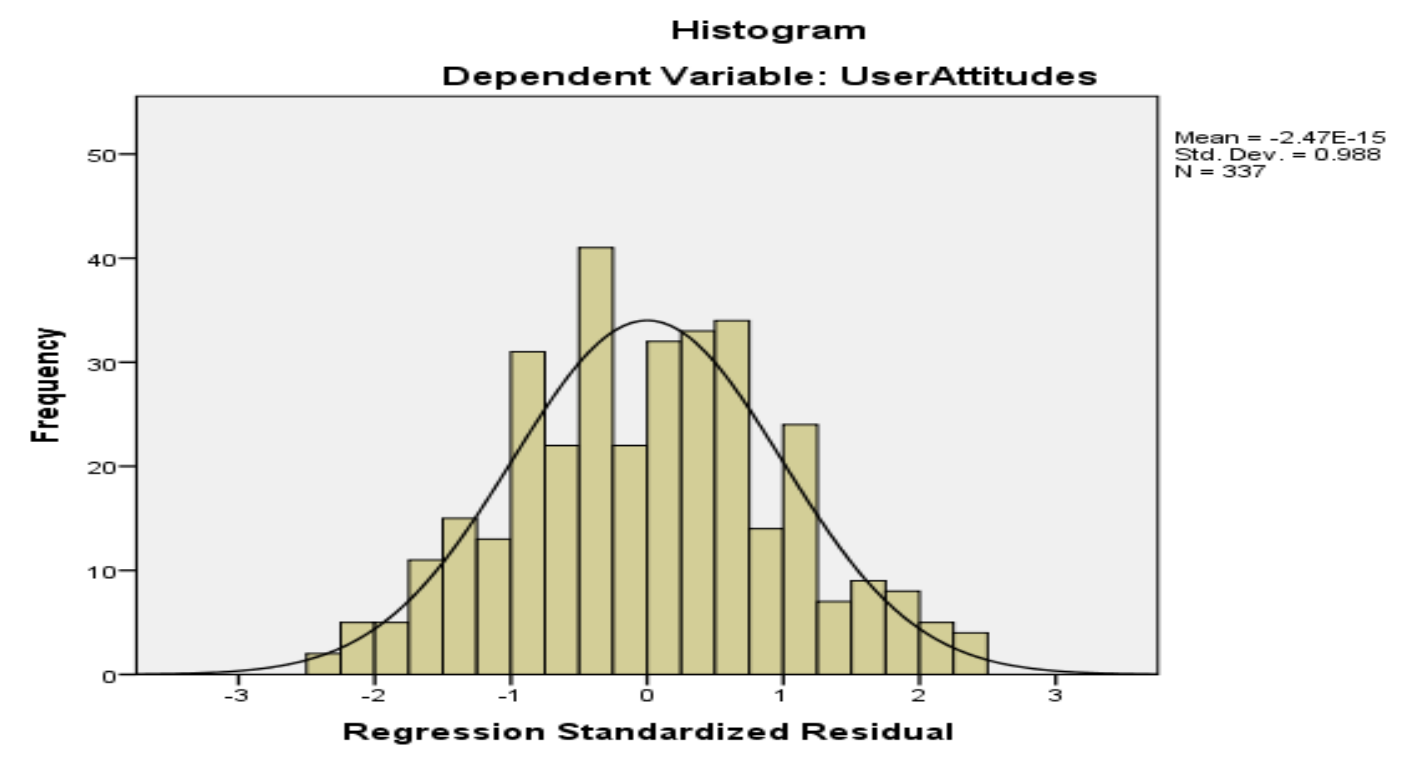

Fig 4 


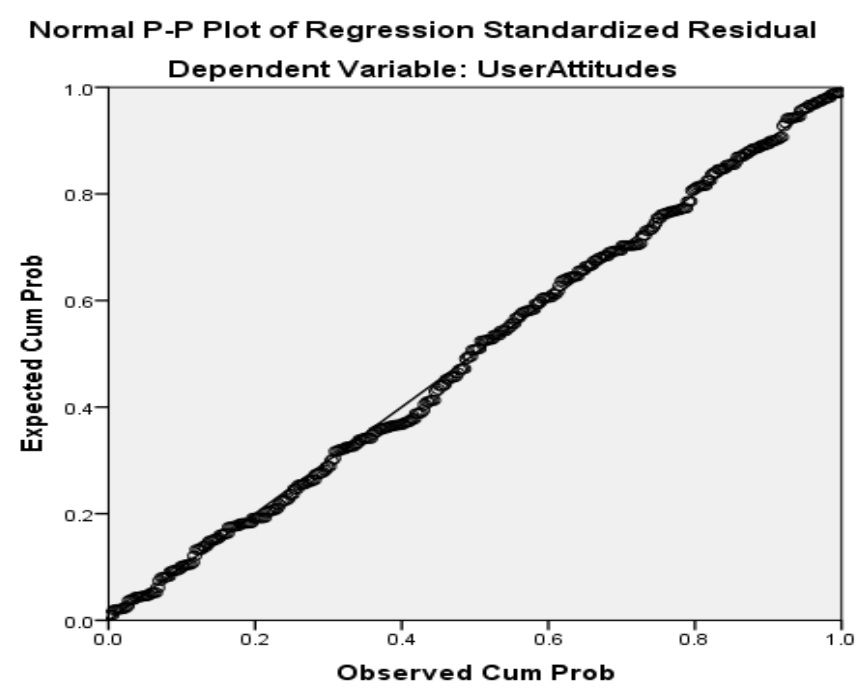

Fig 5

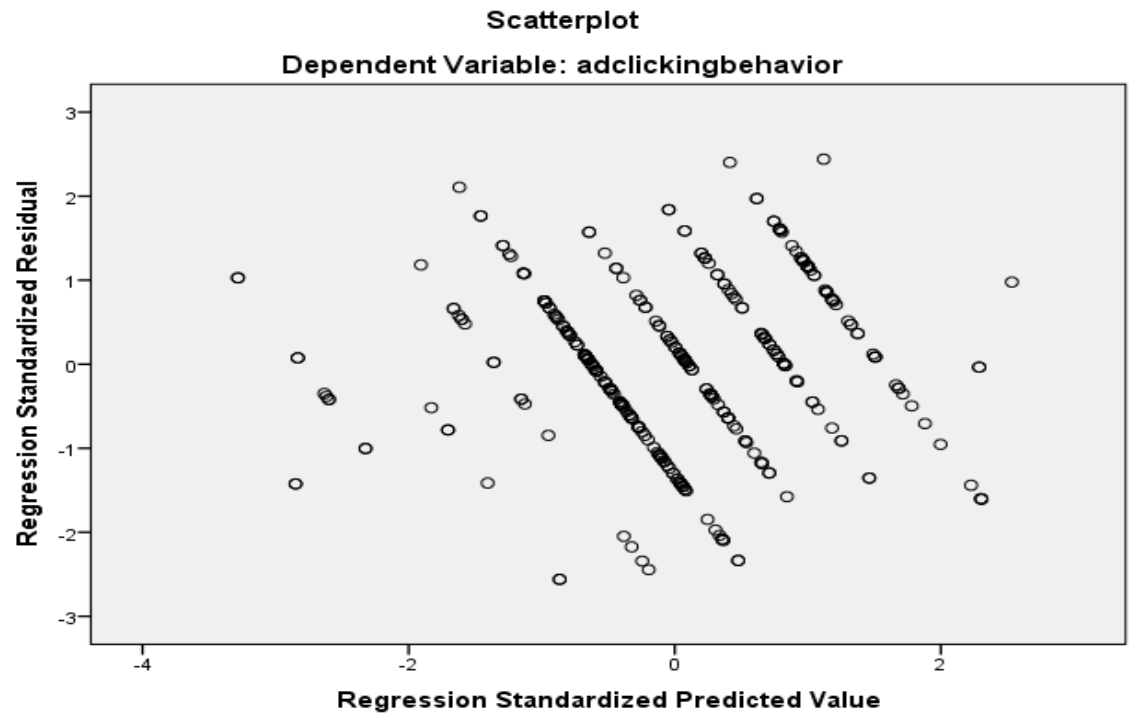

Fig 6

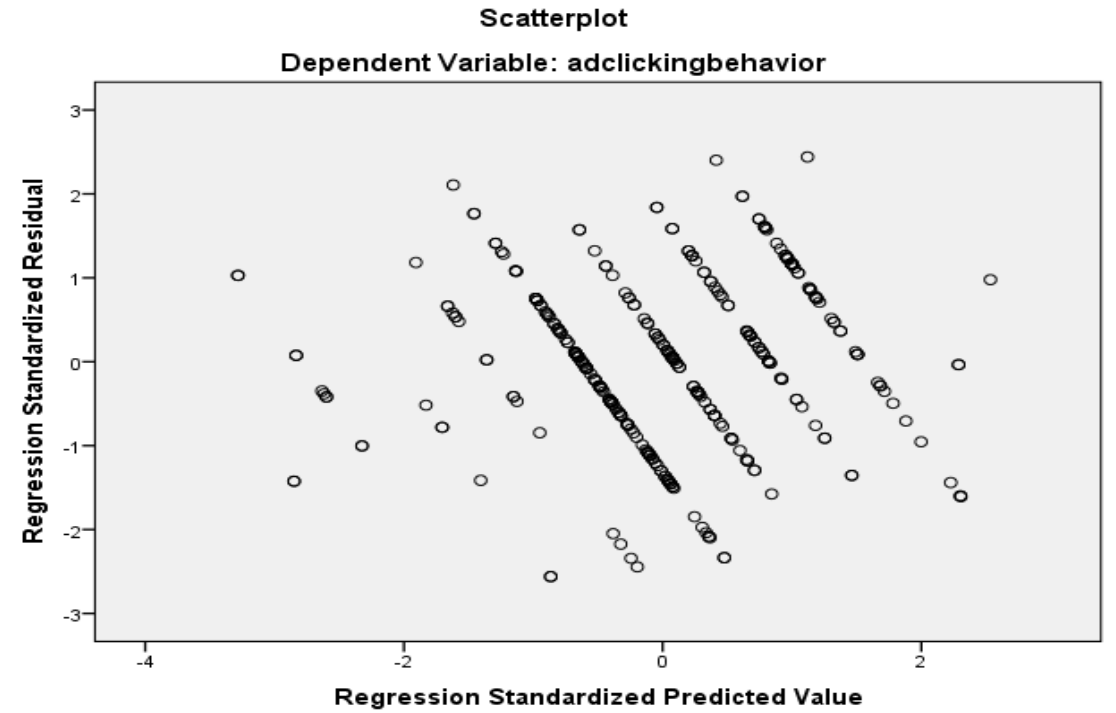

Fig 7 